\title{
Demokrasi ve Yenilenebilir Enerjinin Çevre Kirliliği Üzerine Etkisi: Görünürde İlişkisiz Regresyon Analizi
}

DOI: $10.26466 /$ opus. 888826

\author{
Melike Atay Polat ${ }^{*}$ - Pınar Çuhadar** \\ * Doç. Dr., Mardin Artuklu Üniversitesi, Mardin/Türkiye \\ E-Posta: matay@artuklu.edu.tr \\ ORCID: $0000-0001-9507-5942$ \\ ** Dr. Öğr. Üyesi, Mardin Artuklu Üniversitesi, Mardin/Türkiye \\ E-Posta: pinarozdemircukadar@artuklu.edu.tr \\ ORCID: $\underline{0000-0002-7987-3300}$
}

\section{Öz}

Çevre kirliliğinin azaltılmasına yönelik politika tartışmaları küresel ekonomi gündeminde ön sıralarda yer almaktadır. Bu çalışma çevre kirliliği ve ekonomik büyüme arasında geniş bir literatürün mevcut olmasına ră̆men, demokrasi ve yenilenebilir enerjinin çevre kalitesi üzerine etkisini inceleyen çalışma sayısının sınırlı olması sebebiyle hazırlanmıştır. Bu kapsamda Merkezi ve Doğu Avrupa (Çek Cumhuriyeti, Estonya, Macaristan, Litvanya, Letonya, Polonya, Rusya, Slovakya, Slovenya) ülkelerinde 1995-2018 döneminde demokrasi ve yenilenebilir enerjinin sera gazı emisyonu ve karbon emisyonu (CO2) üzerine etkisi statik panel veri analiziyle incelenmiştir. Çalışmanın Görünürde İlişkisiz Regresyon (SUR) bulguları, ele alınan modellerin sonuçlarının ülkeden ülkeye değiştiğini gösterdiği gibi Çevresel Kuznets Ĕ̆risi (ÇKE) hipotezinin de tüm ülkeler için geçerli olmadiğımı ortaya koymuştur. Bu durumun ortaya çıkmasında büyüme düzeylerini etkileyen ve doğrudan yabancı yatırımlara bağgl olan üretim yapıları arasındaki farklılıların etkili olduğu görülmüştür. Elde edilen sonuçlara göre; Merkezi ve Doğu Avrupa ülkelerinde demokratik kurumların gelişimi ve yenilenebilir enerji yatırımlarına ağıılık verilmesi ile çevresel tahribatlarm önlenmesine katkı sunulabileceği anlaşılmıştır.

Anahtar Kelimeler: Çevresel Kuznets Eğrisi, yenilenebilir enerji, görünürde ilişkisiz regresyon analizi, MDA ülkeleri. 


\title{
Democracy, Renewable Energy and Environmental Pollution Relation: Seemingly Unrelated Regression
}

\begin{abstract}
Policy debates for reducing environmental pollution are at the forefront of the global economy agenda. This study prepared in order to close gap for examining the impact of democracy and renewable energy on environmental quality, despite of wide range of literature between environmental pollution and economic growth. In this context, the effects of democracy and renewable energy on greenhouse gas and carbon dioxide (CO2) emission for Central and Eastern Europe (Czech Republic, Estonia, Hungary, Lithuania, Latvia, Poland, Russia, Slovakia, Slovenia) analyzed by Seemingly Unrelated Regression (SUR) analysis for the period 1995-2018. The findings of SUR were changed country to country and it is supported that Environmental Kuznets Curve hypothesis was not valid for all countries. It is thought that the qrowth level which is affected by production structure is effective in these results. Moreover, improvements related to democratic institutions in Central and Eastern European countries and renewable energy investments can contribute to the prevention of environmental degradation.
\end{abstract}

Keywords: Environmental Kuznets Curve, renewable energy, seemingly unrelated regression (SUR), CCE countries. 


\section{Giriş}

İnsan faaliyetleri neticesinde ortaya çıkan sera gazı ve karbon emisyonunun iklim değişikliği ve küresel ısınmaya olan katkıları, araştırmacılar ve politika yapıcılar tarafından çevre kalitesi konusunun son yıllarda yoğun bir şekilde tartışılmasını gündeme getirmiştir. Gelecek nesillere daha iyi bir yaşam ortamı sunabilmek için dünya çapında karbon emisyonunu kontrol altına almaya yönelik uygulamalar devam etmektedir (Lv, 2017, s.900). Bu kapsamda küresel ısınmayı engellemek ve sera gazı emisyonunu azaltmak suretiyle pekçok ülke Kyoto Protokolünü imzalamıştır (You vd. 2015, s.189). Bununla birlikte Paris Anlaşması karbon emisyonu artışına karşı mücadele etmek amacıyla küresel çapta atılan bir diğer önemli adımdır (Adams ve Acheampong, 2019, s.1).

Çevresel Kuznets Eğrisi (ÇKE) hipotezi, Grosmann ve Krueger $(1991,1995)$ tarafından Kuznets eğrisinin gelir ve çevre kalitesi ilişkisine uyarlanmış halidir. Bu hipoteze göre, başlangıçta gelir artış çevre kirliliğini artırmakta, gelir düzeyi belli bir dönüm noktasına ulaştıktan sonra gelirdeki artış çevre kirliliğini azaltmaktadır (Dinda, 2004, s.433). Küresel ısınmaya karşı mücadele etmek ve çevreyi korumak için uygun politika araçlarının tasarımında ÇKE hipotezinin geçerliliğini test etmek önemlidir. ÇKE hipotezini araştıran ampirik çalışmalarda sonuçlar ülke/ülke grupları, zaman aralığı, kullanılan değişkenlere vs. göre farklılık gösterebilmektedir. Örneğin, mevcut çalışmalarda çevresel kirlilik ve kişi başına gelir arasında doğrusal ilişki, ters-U ilişkisi veya N-şeklinde ilişki bulunmuştur (You vd. 2015, s.189).

Çevre kirliliği sadece gelir düzeyiyle ilişkili değildir. Enerji kullanımı, kentleşme, dış ticaret ve yabanc sermaye gibi pek çok sosyo-ekonomik göstergenin çevre üzerinde önemli etkileri vardır (Sadorsky, 2009; Sadorsky, 2011; Jebli vd., 2013; Shafiei ve Salim, 2014; Aslan vd., 2020). Ülkelerin ekonomik gelişmelerini sağlayabilmeleri adına yaptıkları faaliyetler, enerji talebi artışına yol açmaktadır. Ne var ki bu talebin karşılanmasında daha çok fosil enerji kaynaklarından yararlanılmakta ve bu da çevre kirliliğine neden olmaktadır. Fosil enerji kaynaklarının tükeniyor olması, çevre kirliliğini artırması ve dişa bağımlılığa da yol açması sebebiyle ülkeler tükenmeyen, çevre kirliğine yol açmayan, yeni teknoloji kullanımını gerektiren ve yerli enerji kaynağı olan yenilenebilir enerji kaynaklarını değerlendirmeye başlamışlardır. Dolayısıyla güneş ve hidroelektrik gibi yenilenebilir enerji 
kaynakları yenilenemez enerji kaynakları ile karşılaştırıldığında daha az karbon içerir ve bundan dolayı çevreyi daha az kirletirler.

Çevre kirliliği ekonomik gelişmenin en önemli demografik göstergelerden biri olan kentleşme oranı ile de ilişkilidir. Hızlı kentleşme bir taraftan altyapının gelişmesini, yoksulluğun azalmasını ve sağlık hizmetlerini beraberinde getirirken diğer taraftan yüksek enerji talebi ve tüketimi neticesinde de insan sağlığını, canlıları ve tarımı olumsuz yönde etkileyerek çevre kirliliğine neden olmaktadır (Adams ve Klobodu, 2017, s.2-3).

Serbest ticaretin çevresel etkileri ise üç şekilde ortaya çıkmaktadır: Ölçek etkisi, kompozisyon etkisi ve teknoloji etkisi. Ölçek etkisi ekonomik faaliyetlerin boyutunu değiştirmeyi ifade eder. Ölçek etkisinde çevresel kirlilik ekonomik büyümenin fosil enerji tüketimini artırması sonucunda ortaya çıkar. Komposizyon etkisi mamul mal sepetinin komposizyonunu ifade eder. Kompozisyon etkisi, ticaret politikasındaki değişimlerden kaynaklanmaktadır. Teknoloji etkisi ise, doğrudan yabanc yatırımın temiz teknoloji kullanımını teşvik etmesi sonucunda üretim tekniğinin değişmesini ifade eder (Dinda, 2004).

Doğrudan yabancı sermaye yatırımlarının istihdamı ve üretimi destekleyerek mevcut büyüme oranını hızlandırdığı, teknolojik yeniliklerle birlikte de gelecekteki potansiyel büyümeye katkı sunacağı söylenebilir (Solarin ve Shahbaz, 2015, s.836). Fakat, doğrudan yabancı sermaye yatırımlarının ekonomik büyümeyi teşvik etmesi ile artan üretim faaliyetleri çevresel kalitenin bozulmasına sebep olmaktadır (Tamazin ve Rao, 2010).

Son yıllarda demokratikleşme sürecinin çevresel kalite üzerine etkisinin olup olmadığı da tartışılmaktadır. Yapılan çalışmalara göre demokratikleşmenin çevresel kaliteye etkisinin üç farklı şekilde ortaya çıkabildiği yönünde fikir birliği oluşmuştur. İlk olarak demokratik ülkelerde çevresel kalite ile ilgili bilgi toplama serbestliği, tercihlerini açılayabilmeleri, bireylerin daha iyi organize olmaları gibi sebeplerle politika yapıcılara olan baskılarının çevresel kaliteyi iyileştirdiğine dair kanıtlara ulaşılmıştır. İkinci olarak, demokratik ülkelerin otoriter ülkelere göre daha yüksek bir sera gazına sahip olduğu yönünde çalışmalar bulunmaktadır. Son olarak demokrasinin çevresel kalite üzerine hiçbir etkisinin olmadığı çalışmalara da rastlanmiştır (Lv, 2017, s.900).

$\mathrm{Bu}$ çalışma merkezi planlı ekonomiden piyasa ekonomisine geçerek yapısal ve kurumsal değişim sergileyen (Jorgenson vd., 2014, s.420) ve enerji 
tüketiminde yenilenebilir enerji payının giderek arttığı, yani benzer politikekonomik model ve enerji yapısına sahip olan (Ćetković ve Buzogány, 2020, s.1-2) Merkezi ve Doğu Avrupa ülkeleri için hazırlanmıştır.

Berlin Duvarının yıkılması ile Demirperde ülkeleri olarak da anılan Merkezi ve Doğu Avrupa Ülkeleri için yeni bir dönem başlamıştır. Demokrasi ve serbest piyasa ekonomisine hızla entegre olan Merkezi ve Doğu Avrupa ülkeleri, geçiş sürecinin sosyoekonomik tramvaların bir yana bırakıp yeni küresel sistem içinde yer edinmeye başlamışlardır. Merkezi ve Doğu Avrupa'nın sosyoekonomik verilerine odaklanan endeksler, 2009 ve 2014 yılları arasında 2007 krizinin ardından yaşanan durgunluğun yerini sürekli olarak artan bir refaha bıraktığın, Merkezi ve Doğu Avrupa ile Batı Avrupa arasındaki refah farkının azalmaya devam ettiğini desteklemektedir. Buna rağmen kayıt dişı ekonomiden kaynaklı çalışan yoksulluğu, yaşama ve barınma maliyetlerindeki artışlar, gelir dağılımı adaletsizliği, sağlık sisteminin kapsayıcılığının sınırlı olması gibi faktörlerin gelecekle ilgili beklentileri olumsuz etkilediği de tespit edilmektedir. Nitekim 2000 ile 2017 yılları arasında mal ve hizmet fiyatları, $\mathrm{AB}^{\prime}$ de ortalama \%36 oranında artarken Romanya'da \% 257, Macaristan'da \%98 ve Letonya'da \% 87 oranında artış göstermiştir. Bu sorun alanlarının yanı sıra bu ülkelerin Batı Avrupa'ya kıyasla derin bir demokrasi kültürüne sahip olmamaları yönetişim kalitelerinin istenen düzeye erişmesini de engellemektedir (Griverson vd., 2019; Brien vd., 2019)

Bölge yenilenebilir enerji kaynakları açısından zengindir ve yüksek kişi başına fosil yakıt tüketimini azaltmada enerji verimliliği önlemleri için önemli bir fırsata sahiptir (www.re-focus.net). 2018 yllında yenilenebilir enerjinin payı Polonya'da \%13, Macaristan'da \%8.3, Slovakya'da \%21.5, Estonya'da \%19.7, Litvanya'da \%18.4, Letonya'da \%53.5 ve Slovenya'da \%32.3'tür (EUROSTAT, 2019). Bundan dolayı bölge, yenilenebilir enerji kaynakları dahil temiz enerji projelerinin gelişiminde önemlidir. Ayrıca 2004 yılında Estonya, Litvanya ve Slovenya'nın AB ülkelerine katılmış olması, Dünya Ticaret Örgütüne üyeliklerinin bulunması ve aynı coğrafik konuma sahip olmaları bölgenin jeoekonomik önemini ortaya koymaktadır. $\mathrm{Bu}$ ülkelerdeki enerji çalışmaları ülke çapında, bölge çapında ve $A B$ ülkelerinde enerji talebi açısından önemlidir (Sadorsky, 2011, s.1000). Gelecek on yılda Merkezi ve Doğu Avrupa'nın enerji güvenliğini sağlamak için, küresel perspektifi geliştirmek ve enerji sektöründeki son gelişmeleri takip etmek 
gerekmektedir. Enerji kullanımından kaynaklanan çevresel problemlerin çözümlenmesi ise çok sayıda ülkenin, bölgenin ve/veya uluslar arası organizasyonların işbirliğine bağlı olacaktır (Iordache vd., 2019, s.19037). Archibald vd. (2009)'da geçiş süreci sonrasında Merkezi ve Doğu Avrupa ülkelerinde uygun kurumsal düzenlemeler ve çevre politikaları ile kalkınma hedeflerinin birlikte yürütülebileceğini ortaya koymaktadır. Merkezi Doğu Avrupa ülkeleri üzerine yapılan bir dizi çalışma (Atıcı, 2009; Destek, Ballı ve Manga, 2016; Ho ve Iyke. 2019; Liv, Jiang, Sotnyk, Kubatko ve Almashaqbeh, 2020) ÇKE hipotezi çerçevesinde ekonomik büyümenin çevre kalitesini uzun dönemde olumlu yönde etkilediğini ortaya koymaktadır.

Ekonomik büyümenin çevresel bozulmaya etkisi hakkında geniş bir literatür olmasına rağmen, gelişmekte olan ülkelerde demokrasi ve yenilenebilir enerjinin çevre kalitesine etkisini inceleyen ampirik çalışma sayısı sınırlıdır. Bu sınırlılığın yanı sıra rejim değişimi sonrası kurumsal yapısını liberal ekonomik ve siyasal düzene uyumlaştırma çabasında olan Merkezi ve Doğu Avrupa ülkelerinin, son 25 yılda yakaladığı büyüme trendinin çevresel kalite göstergeleri üzerindeki etkisini incelemek çalışmanın temel motivasyonunu oluşturmaktadır. Bu noktadan hareketle çalışmanın literatüre yapacağı katkıları şu şekilde sıralayabiliriz: Birincisi, Merkezi ve Doğu Avrupa ülkelerinde yenilenebilir enerji-çevresel bozulma-demokrasi ilişkisini ampirik olarak kanıtlayan ilk çalı̧̧madır. İkincisi, bu çalışma Kim vd. (2018)'in ampirik modelini kullanarak örnek alınan ülke grubunda demokrasinin çevresel kalite üzerine bir etkisinin olup olmadığını incelemektedir. Üçüncüsü, demokrasi ve çevre ilişkisini farklı çevresel kirlilik türleri ayrımında ele alarak ampirik sonuçların karşılaştırılmasına olanak sunmaktadır. Dördüncüsü, yenilenebilir enerjinin çevresel kaliteyi iyileştirdiği hipotezini test etmektedir. Beşincisi, farklı modeller ve farklı yöntemler kullanarak ÇKE hipotezini destekleyen sonuçlara ulaşmak istenmektedir.

Çalışmanın beş bölümü bulunmaktadır. Giriş ile başlayan birinci bölümü, demokrasi ve çevre ilişkisine ait literatür takip etmektedir. Üçüncü bölüm materyal ve yöntemden oluşmakta iken, dördüncü bölüm analizden elde edilen bulgulara dayanmaktadır. Sonuç bölümü ile çalışma tamamlanmıştır.

\section{Literatür Taraması}


İlk zamanlarda gelir ve çevresel bozulma arasındaki ilişkinin test edilmesi amacıyla geliştirilen ÇKE hipotezi son dönemlerde gelirin çevresel kaliteyi etkileyen tek faktör olmadığından yola çıkılarak sosyo-ekonomik faktörlerin ve politik araçların etkilerinin de incelenmesini gerekli kılmıştır.

Literatürde ÇKE hipotezini test eden çalı̧̧maların uygulama sonuçları bölgesel ve gelir farklılıklarından dolayı tutarlı çıkmayabilir. Çalışma sonuçlarının tutarlı çıkmasında benzer sosyo-ekonomik özelliklere sahip ve demokratik gelişme gösteren ülkelerin seçilmesi önemli olabilir (Adams ve Acheampong, 2019, s.2).

Ampirik çalışmalar demokrasi ve çevresel kalite arasındaki ilişkinin pozitif ya da negatif yönde olabileceğini göstermiştir. Demokratik ülkelere kıyasla demokratik olmayan ülkelerde çevre kirliliğinin daha fazla olduğunu kanıtlayan çalışmalar arasında Bättig ve Bernauer (2009), Fredriksson ve Neumayer (2013), You vd. (2015), Policardo (2016), Adams ve Klobodu (2017), Lv (2017), Kim vd. (2018), Chou vd.(2019) Adams ve Acheampong (2019) yer almaktadır. Bättig ve Bernauer (2009), iklim değişikliğini" küresel kamusal mal" olması niteliği çerçevesinde ele alarak iklim değişikliği demokrasi ilişkisini 185 ülkeye ait verilerle 1990-2004 yılları için incelemişlerdir. En küçük kareler tahmin edicisinin kullanıldığ çalışmada sınanan hipotezler, demokrasi düzeyi daha yüksek olan ülkelerin iklim değişikliğine karşı yürütülen politikalara daha iyi uyum sağladıkları ve bu politikalara daha çok katkı sunduklarıdır. Elde edilen bulgular, demokrasi düzeyinin iklim değişikliğine karşı yürütülen politikalarda belirleyici bir faktör olduğunu desteklemektedir. Fredriksson ve Neumayer (2013), 87 ülkeyi demokrasi düzeylerine göre sinıflandırarak tarihsel birikimlerin sonucu oluşan demokratik sermaye ile iklim değişikliği politikaları arasındaki ilişkiyi iki aşamalı en küçük kareler yöntemini kullanarak sınamışlardır. Yapılan analiz neticesinde elde edilen bulgular, demokratik sermayenin iklim değişikliği politikalarında etkin rol oynadığını desteklemiş; fakat demokrasinin mevcut düzeyi ile iklim değişikliği politikaları arasında anlamlı bir ilişki olmadığını göstermiştir. Chou vd. (2019), 1990-2013 yılları için Amerika'daki 26 eyalet üzerinde $\mathrm{CO}_{2}$ emisyonu, demokrasi ve enerji ilişkisini kantil regresyon yardımı ile incelemiştir. Kantil regresyon sonucunda elde edilen bulgulara göre bütün kantiller altında demokrasinin enerjinin etkin kullanımı ve karbon emisyonu üzerindeki etkisi anlamlıdır. Buna göre demokrasi, enerji kullanımında etkinliği arttırırken, karbon emisyonu miktarının düşmesini 
sağlamaktadır. Tablo 1, demokrasi ve çevre kalitesi ilişkisini inceleyen uygulamalı çalışmaları özetlemek amacıyla hazırlanmıştır.

Tablo 1. Demokrasi ve çevre kalitesi ilişkisini inceleyen uygulamalı çalışmalar

\begin{tabular}{|c|c|c|c|c|c|}
\hline Yazarlar & $\begin{array}{l}\text { Çalışma Ya- } \\
\text { pilan Ülke }\end{array}$ & $\begin{array}{l}\text { Çalışma Dö- } \\
\text { nemi }\end{array}$ & $\begin{array}{l}\text { Çalışmada } \\
\text { Kullanılan } \\
\text { Değişkenler }\end{array}$ & $\begin{array}{l}\text { Çalışmada } \\
\text { Kullanılan } \\
\text { Yöntem }\end{array}$ & Sonuç \\
\hline $\begin{array}{l}\text { Bättig ve Berna- } \\
\text { uer (2009) }\end{array}$ & 185 ülke & $1990-2004$ & $\begin{array}{l}\text { Demokrasi, ik- } \\
\text { lim değişikliği }\end{array}$ & EKK & $\begin{array}{l}\text { Demokrasi düzeyi } \\
\text { iklim değişikliğine } \\
\text { karşı yürütülen po- } \\
\text { litikalarda belirleyi- } \\
\text { cidir. }\end{array}$ \\
\hline $\begin{array}{l}\text { Fredriksson ve } \\
\text { Neumayer } \\
(2013)\end{array}$ & 87 ülke & $2005-2010$ & $\begin{array}{l}\text { Demokratik } \\
\text { sermaye, iklim } \\
\text { değişikliği }\end{array}$ & 2AEKK & $\begin{array}{l}\text { Demokratik ser- } \\
\text { maye iklim deği- } \\
\text { şikliği politikala- } \\
\text { rında etkindir. }\end{array}$ \\
\hline You vd. (2015) & 24 ülke & $1995-2005$ & $\begin{array}{l}\text { Demokrasi, fi- } \\
\text { nansal ge- } \\
\text { lişme, } \mathrm{CO}_{2} \\
\text { emisyonu }\end{array}$ & $\begin{array}{l}\text { Kantil regres- } \\
\text { yon analizi }\end{array}$ & $\begin{array}{l}\text { Demokrasi ve fi- } \\
\text { nansal gelişme } \mathrm{CO}_{2} \\
\text { emisyonunu azalt- } \\
\text { maktadır. }\end{array}$ \\
\hline Policardo (2016) & 47 geçiş ülkesi & $1950-2002$ & $\begin{array}{l}\text { Demokrasi, } \\
\text { diktatörlük, } \\
\mathrm{CO}_{2} \text { emisyonu }\end{array}$ & $\begin{array}{l}\text { Panel veri ana- } \\
\text { lizi }\end{array}$ & $\begin{array}{l}\text { Demokrasi çevre } \\
\text { kirliliğini azalmak- } \\
\text { tadır. }\end{array}$ \\
\hline $\begin{array}{l}\text { Adams ve Klo- } \\
\text { bodu (2017) }\end{array}$ & $\begin{array}{l}38 \text { Afrika ül- } \\
\text { kesi }\end{array}$ & $1970-2011$ & $\begin{array}{l}\text { Kentleşme, } \\
\text { demokrasi, } \\
\mathrm{CO}_{2} \text { emisyonu }\end{array}$ & $\begin{array}{l}\text { Panel eşbütün- } \\
\text { leşme ve ne- } \\
\text { densellik }\end{array}$ & $\begin{array}{l}\text { Demokrasi çevre } \\
\text { kirliliğini azaltmak- } \\
\text { tadır. }\end{array}$ \\
\hline Kashwan (2017) & 137 ülke & $1995-2005$ & $\begin{array}{l}\text { Eşitsizlik, de- } \\
\text { mokrasi, çevre }\end{array}$ & $\begin{array}{l}\text { Panel veri ana- } \\
\text { lizi }\end{array}$ & $\begin{array}{l}\text { Demokrasi koru- } \\
\text { nan alanları arttır- } \\
\text { maktadır. }\end{array}$ \\
\hline Chou vd. (2019) & $\begin{array}{l}\text { Amerika'da } \\
26 \text { eyalet }\end{array}$ & $1990-2013$ & $\begin{array}{l}\mathrm{CO}_{2} \text { emis- } \\
\text { yonu, demok- } \\
\text { rasi ve enerji }\end{array}$ & $\begin{array}{l}\text { Kantil regres- } \\
\text { yon analizi }\end{array}$ & $\begin{array}{l}\text { Demokrasi çevre } \\
\text { kirliliğini azalmak- } \\
\text { tadır. }\end{array}$ \\
\hline
\end{tabular}

Çevre kalitesi ve demokrasi ilişkisini ÇKE hipotezi ile inceleyen çalışmalara da rastlanmıştır. Arvin ve Lew (2011), çevresel kalite ve demokrasi ilişkisini ÇKE hipotezi çerçevesinde 1976-2003 dönemi için 141 ülkeyi genelleştirilmiş en küçük kareler sabit etkiler tahmincisi kullanarak incelemiştir. Çalışmada bölge ve gelirlerine göre alt gruplara ayrılan ülkelerde tüm alt gruplar için $\mathrm{CO}_{2}$ emisyonu, su kirliliği ve demokrasi arasında anlamlı ilişki tespit edilmiştir. Fakat çalışma bulguları $\mathrm{CO}_{2}$ emisyonu söz konusu olduğunda ÇKE hipotezi ile çelişen bir sonuca ulaşmış; Merkezi Asya ülkeleri dışında gelir düzeyi ve karbon emisyonunun pozitif ilişki içinde olduğu saptanmıştır. Çevre kirliliği ölçütü olarak ormansızlaştırmanın kullanılması halinde ise birkaç alt örnekte ÇKE hipotezi geçerlilik kazanmıştır. Tablo 2, demokrasi ve çevre kalitesi ilişkisini ÇKE 
hipotezi çerçevesinde inceleyen uygulamalı çalışmaları özetlemek amacıyla hazırlanmıştır.

Tablo 2. Demokrasi ve çevre kalitesi ilişkisini ÇKE hipotezi çerçevesinde inceleyen uygulamalı çalışmalar

\begin{tabular}{|c|c|c|c|c|c|}
\hline Yazarlar & $\begin{array}{l}\text { Çalışma Yapı- } \\
\text { lan Ülke }\end{array}$ & $\begin{array}{l}\text { Çalışma } \\
\text { Dönemi }\end{array}$ & $\begin{array}{l}\text { Çalışmada Kulla- } \\
\text { nılan Değişken- } \\
\text { ler }\end{array}$ & $\begin{array}{l}\text { Çalışmada Kulla- } \\
\text { nılan Yöntem }\end{array}$ & $\begin{array}{l}\text { Sonuç/ÇKE } \\
\text { İlişkisi }\end{array}$ \\
\hline $\begin{array}{l}\text { Arvin ve Lew } \\
\text { (2011) }\end{array}$ & 141 ülke & $1976-2003$ & $\begin{array}{l}\mathrm{CO}_{2} \text { emisyonu, su } \\
\text { kirliliği, demok- } \\
\text { rasi }\end{array}$ & $\begin{array}{l}\text { Genelleştirilmiş } \\
\text { EKK }\end{array}$ & Ters U-şeklinde \\
\hline Akın (2014) & BRICS ülkeleri & $2001-2011$ & $\begin{array}{l}\mathrm{CO}_{2} \text { emisyonu, } \\
\text { gelir, kurumsal } \\
\text { kalite }\end{array}$ & $\begin{array}{l}\text { Panel veri regres- } \\
\text { yon analizi }\end{array}$ & Ters U-şeklinde \\
\hline Lv (2017) & $\begin{array}{l}19 \text { gelişmekte } \\
\text { olan ülke }\end{array}$ & $1997-2010$ & $\begin{array}{l}\mathrm{CO}_{2} \text { emisyonu, } \\
\text { gelir, demokrasi }\end{array}$ & $\begin{array}{l}\text { Kantil regresyon } \\
\text { analizi }\end{array}$ & Ters U-şeklinde \\
\hline $\begin{array}{l}\text { Topal ve Haya- } \\
\text { loğlu (2017) }\end{array}$ & 124 ülke & 2000-2014 & $\begin{array}{l}\text { Politik risk, yöne- } \\
\text { tişim, demokrasi, } \\
\text { çevre perfor- } \\
\text { mansı }\end{array}$ & $\begin{array}{l}\text { Sabit etkiler, ras- } \\
\text { sal etkiler, GMM }\end{array}$ & $\begin{array}{l}\text { ÇKE ilişkisi } \\
\text { yoktur. }\end{array}$ \\
\hline Kim vd. (2018) & $\begin{array}{l}78 \text { yüksek ge- } \\
\text { lirli ülke, } 53 \\
\text { düşük gelirli } \\
\text { ülke }\end{array}$ & 2014 & $\begin{array}{l}\mathrm{CO}_{2} \text { emisyonu, } \\
\text { gelir, demokrasi }\end{array}$ & EKK & Ters U-şeklinde \\
\hline $\begin{array}{l}\text { Hotunluoğlu ve } \\
\text { Yilmaz (2018) }\end{array}$ & Türkiye & $1972-2011$ & $\begin{array}{l}\text { Demokrasi, çev- } \\
\text { resel politikalar }\end{array}$ & $\begin{array}{l}\text { Zaman serisi ana- } \\
\text { lizi }\end{array}$ & $\begin{array}{l}\text { ÇKE ilişkisi } \\
\text { yoktur. }\end{array}$ \\
\hline Wang vd. (2018) & G20 ülkeleri & 2000-2014 & $\begin{array}{l}\text { Demokrasi, poli- } \\
\text { tik küreselleşme, } \\
\text { kentleşme, PM2.5 } \\
\text { emisyonu }\end{array}$ & $\begin{array}{l}\text { Kantil regresyon } \\
\text { analizi }\end{array}$ & Ters U-şeklinde \\
\hline $\begin{array}{l}\text { Adams ve Ac- } \\
\text { heampong } \\
(2019)\end{array}$ & $\begin{array}{l}\text { 46n.ş Sahra } \\
\text { Altı Afrika Ül- } \\
\text { kesi }\end{array}$ & $1980-2015$ & $\begin{array}{l}\text { Demokrasi, yeni- } \\
\text { lenebilir enerji, } \\
\text { karbon emisyonu } \\
\text { doğrudan ya- } \\
\text { bancı sermaye, ti- } \\
\text { cari açılık, nüfus, } \\
\text { gelir }\end{array}$ & $\begin{array}{l}\text { Dengesiz panel } \\
\text { veri analizi }\end{array}$ & $\begin{array}{l}\text { ÇKE ilişkisi } \\
\text { yoktur. }\end{array}$ \\
\hline
\end{tabular}

Lv (2017), kantil regresyon analizi yaparak 1997-2010 dönemi için 19 gelişmekte olan ülkede demokrasi ve gelirin $\mathrm{CO}_{2}$ emisyonu üzerine etkisini ÇKE hipotezi kapsamında incelemiştir. Çalışma sonucunda belli bir gelir seviyesine ulaşan ülkede demokrasinin $\mathrm{CO}_{2}$ emisyonunu azalttığını göstermiştir. Buna karşllık, düşük gelirli ülkelerde yüksek gelirli ülkelere göre demokrasi hava kalitesini pozitif yönde etkilemektedir. Adams ve Acheampong (2019) çalışmasında demokrasi ve yenilenebilir enerjinin karbon emisyonuna etkisini 46 Sahra Altı Afrika Ülkesi için 1980-2015 
döneminde dengesiz panel veri metodu kullanarak analiz etmişlerdir. Çalışmada demokrasi ve yenilenebilir enerjinin karbon emisyonunu azalttığ1 sonucuna ulaşmışlardır. Bununla birlikte, doğrudan yabancı sermaye, ticari açıklık, nüfus ve ekonomik büyüme Sahra Altı Afrika ülkelerinde karbon emisyonunu etkilemektedir. Diğer taraftan bu çalışmada ÇKE hipotezi desteklenmemiştir.

\section{Metaryal ve Yöntem}

Çalışmada geçiş sürecini tamamlamış dokuz Merkezi ve Doğu Avrupa ülkesi (Çek Cumhuriyeti, Estonya, Macaristan, Litvanya, Letonya, Polonya, Rusya, Slovakya, Slovenya) için Çevresel Kuznets Eğrisi Hipotezi (ÇKE)'nin geçerliliği, demokrasi ve yenilenebilir enerji değişkenleri de dikkate alınarak sınanmaktadır. İlgili ülkelerin veri setlerinin sınırlılığı nedeni ile ele alınan dönem 1995-2018 yılları ile kısıtlı kalmıştır. Merkezi ve Doğu Avrupa ülkelerinde ÇKE'nin geçerliliğinin incelenmesi sırasında yapılan uygulamanın sapmasız sonuçlar vermesi için hem ülkeler arası korelasyonu dikkate alan hem de zaman boyutu birim sayısından büyük panel veri kullanımına uygun Görünürde İlişkisiz Regresyon tahmincisi kullanılmıştır.

\section{Yöntem}

Panel veri modelleri, zaman serisi veya yatay kesit analizi ile incelenmesi güç olan ekonomik konuların ekonometrik analizine olanak tanıyan bir yöntemdir. Bu yöntemle birlikte gözlenemeyen, yanlış ölçümlenmiş veya analize dâhil edilmemiş değişkenlerin kontrol edilebilmesi mümkün hale gelmektedir (Hurlin, 2018). Panel veri kullanımının avantajlarından bir diğeri yatay kesit boyutuna zaman boyutunun eklenmiş olmasıyla küçük örneklem boyutunda dahi birim kök testlerinin gücünün arttırmasına olanak tanımasıdır. Fakat zaman serisinden farklı olarak panel verilerde birim kök testlerinin yapılmasında kullanılan spesifikasyonlarda dikkate alınması gereken iki özellik vardır. Bu özelliklerden biri panel veriyi oluşturan birimlerin heterojenliği, diğeri ise birimler arası yatay kesit bağımlılığıdır. Bu bağlamda panel birim kök testleri, panel birimleri boyunca kalıntılar arasındaki korelasyona izin vermesine bağlı olarak ikiye ayrilmaktadır. Yatay kesit bağımlılığına izin veren testler "ikinci nesil birim kök testleri" olarak 
adlandırılmaktadır. İkinci nesil panel birim kök testleri faktör yapısını dikkate alan testler ve hata terimlerinin kovaryans matrisine herhangi bir kisit getirmeyen testler olarak da gruplandırılabilmektedir (Hurlin ve Mignon, 2007).

Bu bakımdan Breusch ve Pagan (1980) ve Pesaran (2004) tarafindan geliştirilen LM test istatistiği kullanılarak yatay kesit bağımlılığı sınamasına ihtiyaç duyulmaktadır. BP LM Testi, en küçük kareler yöntemi ile belirlenen yatay kesit kalıntılarının korelasyon katsayılarının karelerinin toplamına bağlı olarak oluşturulan bir testtir. Tahmin hataları arasındaki yatay kesitsel korelasyonu göstermek üzere boş hipotezi yatay kesitsel korelasyonun olmadığını söyleyen CDıмı test istatistiği kullanılmaktadır (Güloğlu ve Ivrendi, 2010:384). CDцм1 sabit N ve T $\rightarrow \infty^{\prime}$ a giderken kullanılırken Pesaran (2004) tarafından geliştirilen CDLM2 asimtotik olarak normal dağılımı sahiptir ve yatay kesit bağımlılığını saptamakta kullanılan diğer bir testtir.

Panel veri serilerinin homojenliğinin sinanmasında ise Pesaran ve Yamagata (2008) tarafından önerilen $\widetilde{\Delta}$ (delta) testine başvurulacaktır. Swamy(1970) tarafından geliştirilen ve küçük örneklemde kullanılan homojenlik testine dayalı olan $\tilde{\Delta}$ testi, yatay birimler için regresyon hata terimlerini klasik en küçük kareler yöntemi yerine havuzlanmış sabit etkiler modelinden elde etmektedir. Test, birim eğimlerin kendi göreli kesinlik derecesi ile ağırlıklandırılmış yatay kesit dağılımını kullanmayı amaçlamaktadır (Pesaran ve Yamagata, 2008). Hipotez sinamasında boş hipotez Ho tüm eğimlerin homojen olduğunu, alternatif hipotez ise en az bir birim için eğimlerin homojen olmadığını ifade etmektedir.

$\mathrm{T}>\mathrm{N}$ iken panel veride yatay kesit bağımlılığının tespit edilmesi durumunda kullanılan ikinci nesil testlerden biri de Çok değişkenli Genişletilmiş Dickey Fuller Testidir. Görünüşte İlgisiz Regresyon mantığına dayalı olarak oluşturulan MADF birim kök testi, temelde en küçük kareler tahmincisi ile elde edilen hata terimlerinin kovaryans matrisine çok değişkenli Genelleştirilmiş En Küçük Kareler yönteminin uygulanmasına dayanmaktadır. MADF testi otoregresif katsayıların panel boyunca özdeş olduğu varsayımını gevşetmektedir. $\mathrm{H}_{0}$ birim kök boş hipotezi standart Wald test istatistiği ile elde edilmektedir (Taylor ve Sarno, 1998). Pesaran (2007) ise yatay kesit bağımlılı̆ının olmadığını söyleyen boş hipotezin red edilemediği heterojen panellerde tahmin edilen faktörlerden sapmalara dayalı birim kök testleri yerine standart ADF testine gecikmeli değerlerin yatay kesit ortalaması 
ve birimlerin birinci farklarını ekleyerek küçük örneklemde de etkin sonuç verebilen yatay kesitsel genişletilmiş Dickey Fuller (CADF ) birim kök testine ulaşmıştır.

Panel veri oluşturulurken $N$ birim sayısının küçük veya büyük olması Tip I veya Tip II hatalara neden olabilmektedir. Bu nedenle kısa ve uzun panellerin kurgulanması ve analiz edilmesi süreci dikkat gerektirmektedir (Park, 2011). Heterojen ve birimler arası korelasyonun bulunduğu panel veride $\mathrm{T}>\mathrm{N}$ durumunda sistemin çözümü için Görünürde İlişkisiz Regresyon (GİR) tahmincisine başvurulmaktadır. Farklı ülkeler için kurulan modellerin benzer faktörler tarafından etkilenmesi hata terimlerinin korelasyona sahip olmasına neden olmaktadır. Bu durumda Zellner (1962) tarafindan önerilen GİR tahmincisinin kullanılması modeller arasındaki korelasyonun neden olacağı etkinlik kayıplarını bertaraf etmektedir (Yerdelen Tatoğlu, 2020).

\section{Model ve Veri Seti}

Merkezi ve Doğu Avrupa ülkelerinde (Çek Cumhuriyeti, Estonya, Macaristan, Litvanya, Letonya, Polonya, Rusya, Slovakya, Slovenya) Çevresel Kuznets Eğrisi Hipotezi'nin geçerliliğinin yanı sıra karbon (seragazı) emisyonu düzeyi üzerinde demokrasi ve yenilenebilir enerjinin etkisini sinamak üzere Kim vd. (2018), Ho ve Iyke (2019) Liv vd. (2020) çalışmasından hareketle belirlenen değişkenlerle birlikte denklem 1'de gösterilen model kullanılacaktir.

$$
\mathrm{E}_{\mathrm{it}}=\propto+\beta D_{i t}+\gamma_{1} Y_{i t}+\gamma_{2} Y_{i t}{ }^{2}+\delta_{i} C_{i}+\varepsilon \mathrm{t}
$$

$\mathrm{E}$, i ülkesinin çevre kalitesi göstergesi, $\mathrm{D}_{\text {it }}$ i ülkesindeki demokrasi düzeyi,

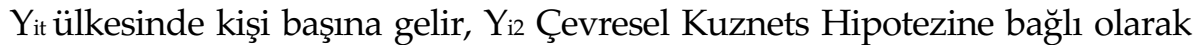
değişkenler arasındaki ilişkinin konkav şekle sahip olmadığını görmek üzere kişi başına gelirin karesi, $C_{i t}$ ise diğer kontrol değişkenlerini içermektedir. Çalışmada kullanılacak değişkenler ve genel özellikleri Tablo 3'te özetlenmiştir.

Tablodan izlendiği üzere iki çevre kalitesi göstergesi $\left(\mathrm{CO}_{2}\right.$ fuel, ve Seragazı) bağımlı değişken olarak kullanılmış; böylelikle iki model oluşturulmuş ve elde edilen sonuçların kıyaslanabilmesi hedeflenmiştir. Bağımsız değişken, liberaldemokrasi, kompozit endeks olarak hesaplanan ve liberal demokrasinin hukukun üstünlüğü, denge denetim gibi genel özelliklerini kapsayan bir veridir. Kontrol değişkenleri kişi başına gelir, uluslararası 
serbest ticaret, doğrudan yabancı sermaye girişleri, yenilenebilir enerji, fosil yakıt ve şehirleşme düzeyidir. Gelir göstergesi olarak satın alma gücü paritesi ile enflasyondan arındırılmış kişi başına gelir diğer değişkenler gibi analizde logaritması alınarak kullanılmıştır. Çevresel Kuznets Eğrisi Hipotezi'nin sınanmasında kullanılacak değişkenlere ait tanısal istatistikler Tablo 3 'te sunulmuştur.

Tablo 4'te tanısal istatistikler, değişkenler arasındaki ölçek farklılıklarını göstermektedir. Doğrudan yatırımlar ve şehirleşme oranıysa (\%) büyüklüğe sahipken bağımlı değişkenler ton birimi ile gösterilmekte ve standart sapmaları diğer değişkenlere göre yüksek değerler almaktadır. Demokrasi ve uluslararası serbest ticaret kompozit endekslerdir. Demokrasi 0-1 arasında değerler almaktadır. En yüksek liberal demokrasi değeri 0.857 iken en düşük değer 0.107 'dir. Bağımlı değişkenlerin diğer değişkenler arasındaki ölçek problemlerini gidermek ve seriler arasındaki farkları azaltmak için logaritmaları alınarak kullanılmıştır. Değişkenlerin orijinal ve logaritmaları alınmış değerleri kıyaslamaya olanak tanıması amacıyla tabloda sunulmuştur.

Tablo 3. Değişkenler ve genel özellikler

\begin{tabular}{|c|c|c|c|c|}
\hline Değişkenler & & $\begin{array}{l}\text { Veri } \\
\text { seti }\end{array}$ & Veri Kaynağı & Tanım (Birim) \\
\hline \multirow[t]{2}{*}{$\begin{array}{l}\text { Bağımlı De- } \\
\text { ğişkenler }\end{array}$} & Co2fuel & oecd_airqty_t1 & $\begin{array}{l}\text { Ekonomik Kal- } \\
\text { kınma ve İşbir- } \\
\text { liği Örgütü } \\
\text { (OECD) }\end{array}$ & $\begin{array}{l}\text { Fuel yakıtın yanmasından kay- } \\
\text { naklanan CO2 emisyonunu } \\
\text { miktarını göstermektedir.(Ton) }\end{array}$ \\
\hline & Seragazı & $\begin{array}{l}\text { oecd_- } \\
\text { greenhouse_t1 }\end{array}$ & $\begin{array}{l}\text { Ekonomik Kal- } \\
\text { kınma ve İşbir- } \\
\text { liği Örgütü } \\
\text { (OECD) }\end{array}$ & $\begin{array}{l}\text { Seragazı emisyonunu göster- } \\
\text { mektedir.(Ton) }\end{array}$ \\
\hline $\begin{array}{l}\text { Bağımsız } \\
\text { Değişken }\end{array}$ & $\begin{array}{l}\text { Liberaldemok- } \\
\text { rasi }\end{array}$ & vdem_libdem & $\begin{array}{l}\text { Varieties of De- } \\
\text { mocracy (V- } \\
\text { Dem) Project }\end{array}$ & $\begin{array}{l}\text { Sivil haklar, hukukun üstün- } \\
\text { lüğü hükümetin sınırlanması } \\
\text { gibi demokrasinin kalitesini } \\
\text { gösteren değişkenleri içermek- } \\
\text { tedir. Endeks } 0-1 \text { arasında değer } \\
\text { almaktadır. }\end{array}$ \\
\hline \multirow[t]{2}{*}{$\begin{array}{l}\text { Kontrol } \\
\text { Değişkenleri }\end{array}$} & $\begin{array}{l}\text { kişibaşınagelir } \\
\text { kişibaşınagelir }^{2}\end{array}$ & $\begin{array}{l}\text { wdi_gdp } \\
\text { cappppcon2011 }\end{array}$ & $\begin{array}{l}\text { Dünya Bankası } \\
\text { Kalkınma Gös- } \\
\text { tergeleri (WBDI) }\end{array}$ & $\begin{array}{l}\text { Satın alma gücü paritesine } \\
\text { (PPP) göre kişi başına GSYIH } \\
\text { değerini göstermektedir (ABD } \\
\text { Dolar). }\end{array}$ \\
\hline & Serbestticaret & fi_ftradeint & Fraser Institute & $\begin{array}{l}\text { Uluslararası ticarette vergiler, } \\
\text { düzenleyici kıstllar, ticaret sek- } \\
\text { törünün fiili büyüklüğü } \\
\text { resmi döviz kuru ve gayri resmi } \\
\text { kur arasındaki fark, }\end{array}$ \\
\hline
\end{tabular}




\begin{tabular}{|c|c|c|c|}
\hline & & & $\begin{array}{l}\text { uluslararası sermaye piyasa } \\
\text { kontrollerini gösteren bir en- } \\
\text { dekstir. }\end{array}$ \\
\hline Yenenerji & $\begin{array}{l}\text { oecd_ } \\
\text { rnewable_t1 }\end{array}$ & $\begin{array}{l}\text { Ekonomik Kal- } \\
\text { kınma ve İşbir- } \\
\text { liği Örgütü } \\
\text { (OECD) }\end{array}$ & $\begin{array}{l}\text { Yenilenebilir kaynakların enerji } \\
\text { arzına katkısını göstermektedir. } \\
\text { (Yüzde) }\end{array}$ \\
\hline $\begin{array}{l}\text { Doğrudan yatı- } \\
\text { rim }\end{array}$ & wdi_fdiin & $\begin{array}{l}\text { Dünya Bankası } \\
\text { Kalkınma Gös- } \\
\text { tergeleri (WBDI) }\end{array}$ & $\begin{array}{l}\text { Bu seri resmi kayıtlarda yer } \\
\text { alan, yabancı yatırımcılardan } \\
\text { gelen net girişlerin GSYİH'ye } \\
\text { bölünmüş değerini göstermek- } \\
\text { tedir. (Yüzde) }\end{array}$ \\
\hline Şehirleşme & wdi_popurb & $\begin{array}{l}\text { Dünya Bankası } \\
\text { Kalkınma Gös- } \\
\text { tergeleri (WBDI) }\end{array}$ & $\begin{array}{l}\text { Ulusal istatistik büroları tarafın- } \\
\text { dan tanımlanan kentsel alan- } \\
\text { larda yaşayan insanların toplan } \\
\text { nüfusa oranını göstermekte- } \\
\text { dir.(Yüzde) }\end{array}$ \\
\hline
\end{tabular}

Kaynak: Quality of Government Institute ${ }^{1}, 2020$

Tablo 4. Tanisal istatistikler

\begin{tabular}{lllll}
\hline Değişken & Ortalama & Standart Hata & Maximum & Minimum \\
\hline Co2fuel & 226.490 & 455.508 & 6.7 & 1604.7 \\
InCo2fuel & 3.91 & 1.637 & 1.902 & 7.380 \\
Seragazi & 357380.3 & 763334.5 & 10512.54 & 2674246 \\
InSeragazi & 11.165 & 1.650 & 9.260 & 14.80 \\
Liberaldemokrasi & 0.700 & 0.195 & 0.107 & 0.857 \\
Kişibaşınagelir & 21428.6 & 5922.352 & 8283.84 & 33.435 \\
InKişibaşınagelir & 9.93 & 0.309 & 9.022 & 10.417 \\
Serbestticaret & 78.46 & 10.987 & 44.2 & 88 \\
lnserbestticaret & 4.35 & 0.16 & 3.79 & 4.48 \\
Yenenerji & 0.109 & 0.91 & 0.024 & 0.426 \\
Fosilyakıt & 70.29 & 20.62 & 8.75 & 102.67 \\
Infosilyakit & 4.18 & 0.44 & 2.17 & 4.63 \\
Doğrudanyyattrum & 4.286 & 7.520 & -46.769 & 54.868 \\
Şehirleşme & 65.239 & 7.255 & 50.622 & 74.643 \\
Inşehirleşme & 4.17 & 0.12 & 3.92 & 4.31 \\
\hline
\end{tabular}

Tanısal istatistikler çevre kalitesi göstergelerinin standart hatalarının yüksek olduğunu ve ülkeler arasında gözle görülür düzeyde değişim bulunduğunu teyit etmektedir. Değişkenlere uygulanan logaritma alma işlemleri, serideki farkların azaltılması ile standart hataların küçülmesini sağlamış ve uygulama bulgularının daha anlamlı değerlendirilmesine olanak tanımıştır.

\footnotetext{
1 Yönetim Kalitesi Enstitüsü Göteborg Üniversitesi bünyesinde faaliyet gösteren ve politik ekonomi alanında kullanılan tüm veri setlerini tek platformda sunan bir veri tabanına sahiptir.
} 


\section{Panel Veri Öntest Bulgulan}

Tablo 5'te Breusch ve Pagan (1980) ve Pesaran (2004) yatay kesit bağımlılık testi sonuçları gösterilmektedir. Test istatistiklerinin olasılık değerlerine göre yatay kesitsel korelasyonun olmadığını söyleyen boş hipotez kabul edilemez. Buna göre birimler arasında yatay kesit bağımlılı̆̆ 1 vardır. Model 1 ve Model 2 için de yatay kesit bağımlılığı testi yapılmış ve yatay kesitsel korelasyonun olmadığını söyleyen boş hipotez kabul edilememiştir.

Tablo 5. Yatay kesit bağımlılı̆̆ı testleri sonuçları

\begin{tabular}{llll}
\hline Değişken & $\begin{array}{l}\text { CD } \\
\text { (prob) }\end{array}$ & $\begin{array}{l}\text { CDLM2 } \\
\text { (prob) }\end{array}$ & H0 Karar \\
\hline InCo2fuel & 0.000 & 0.000 & Red \\
InSeragazı & 0.000 & 0.000 & Red \\
Liberaldemokrasi & 0.000 & 0.000 & Red \\
Inkişibaşınagelir & 0.000 & 0.000 & Red \\
Yenenerji & 0.000 & 0.000 & Red \\
Serbestticaret & 0.000 & 0.000 & Red \\
InFosilyaktt & 0.000 & 0.000 & Red \\
Doğrudanyattrim & 0.000 & 0.000 & Red \\
Şehirleşme & 0.000 & 0.000 & Red \\
Model 1 & 0.004 & 0.001 & Red \\
Model 2 & 0.000 & 0.000 & Red \\
\hline
\end{tabular}

Tablo 6'da yer alan homojenlik testi sonuçlarına göre ise tüm eğimlerin homojen olduğunu söyleyen boş hipotez kabul edilememektedir. Bu noktada istisna olan tek değişken doğrudan yatırım değişkenidir. Heterojen özellik gösteren değişkenler için yatay kesit bağımlılığı ve heterojenlik özelliklerini dikkate alan CADF, doğrudan yatırım değişkeni için MADF birim kök testlerine başvurulması uygun görülmüştür.

Tablo 6. $\tilde{\Delta}$ Homojenlik testi sonuçları

\begin{tabular}{lllll}
\hline Değişkenler & \multicolumn{2}{l}{ Co2fuel (prob) } & \multicolumn{2}{l}{ Seragazı(prob) } \\
& $\tilde{\Delta}$ & $\tilde{\Delta}_{\text {adj }}$ & $\tilde{\Delta}$ & $\tilde{\Delta}_{\text {adj }}$ \\
\hline Liberaldemokrasi & 0.000 & 0.000 & 0.000 & 0.000 \\
InKişibaşınagelir & 0.000 & 0.000 & 0.000 & 0.000 \\
Yenenerji & 0.000 & 0.000 & 0.000 & 0.000 \\
Fosilyakit & 0.000 & 0.000 & 0.000 & 0.000 \\
Serbestticaret & 0.000 & 0.000 & 0.000 & 0.000 \\
Doğrudanyatırım & 0.607 & 0.581 & 0.825 & 0.813 \\
Şehirleşme & 0.000 & 0.000 & 0.000 & 0.000
\end{tabular}




\begin{tabular}{lllll} 
Model & 0.000 & 0.000 & 0.000 & 0.000 \\
\hline
\end{tabular}

Tablo 7'de MADF birim kök testi sonuçlarına göre doğrudan yatırım değişkeninde MADF test istatistiği kritik değerlerden büyük olduğu için serilerin durağan olmadığını I(1) söyleyen boş hipotez ret edilmektedir. Bu durumda seri birim kök içermemektedir. Özellik gösteren değişkenler için yatay kesit bağımlılığı ve heterojenlik özelliklerini dikkate alan CADF, doğrudan yatırım değişkeni için MADF birim kök testlerine başvurulması uygun görülmüştür.

Tablo 7. MADF birim kök testi sonuçları

\begin{tabular}{|c|c|c|c|c|c|c|}
\hline & 1. gecikme & & 2. gecikme & & 3. gecikme & \\
\hline Değişken & $\begin{array}{l}\text { MADF } \\
\text { test istatistiği }\end{array}$ & $\begin{array}{l}\text { Kritik } \\
\text { Değer } \\
(0.05)\end{array}$ & $\begin{array}{l}\text { MADF test is- } \\
\text { tatistiği }\end{array}$ & $\begin{array}{l}\text { Kritik } \\
\text { Değer } \\
(0.05)\end{array}$ & $\begin{array}{l}\text { MADF test } \\
\text { istatistiği }\end{array}$ & $\begin{array}{l}\text { Kritik } \\
\text { Değer } \\
(0.05)\end{array}$ \\
\hline Doğrudanyyatırım & 111.095 & 33.17 & 105.991 & 34.737 & 72.723 & 36.62 \\
\hline
\end{tabular}

Tablo 8. CADF birim kök testi

\begin{tabular}{llll}
\hline Değişkenler & Sabitsiz ve trendsiz & Sabitli & Sabitli ve trendli \\
\hline InCo2fuel & -1.196 & -1.480 & -3.194 \\
InSeragazı & -1.01 & -1.25 & -2.645 \\
Inliberaldemokrasi & -0.991 & -1.515 & -2.228 \\
InFosilyaktt & 1.059 & -0.391 & -0.790 \\
InKişibaşınagelir & -1.404 & -2.161 & -1.751 \\
InSerbestticaret & -3.329 & -3.523 & -3.713 \\
InŞehirleşme & -2.160 & -0.302 & -1.721 \\
InYenenerji & -0.642 & -2.498 & -3.063 \\
\hline
\end{tabular}

Not: CIPS istatistiŏinin kritik değerleri Pesaran (2007), tablo 2a, 2b ve 2c'den elde edilmiştir. 0.01, 0.05, 0.10 anlamlllk değeri için kritik değerler sabitsiz model için strasıyla 1.85, -1.61, -1.49, sabitli model için $-2.51,-2.25,-2.12$, sabitli ve trendli model için $-3.30,-2.94,-2.76$ olarak belirlenmişstir.

Tablo 8' de CADF sonuçlarına göre lnSerbestticaret değişkeni dışında tüm değişkenlerde birim kök olduğunu söyleyen boş hipotez red edilememektedir. Bu durumda serilerin birinci farkları alınarak tekrar birim kök testi uygulanmıştır.

Tablo 9. CADF birim kök testi I(1)

\begin{tabular}{llll}
\hline Değişkenler & Sabitsiz ve trendsiz & Sabitli & Sabitli ve trendli \\
\hline dlnCo2fuel & -4.449 & -4.531 & -4.618 \\
dlnSeragazı & -4.368 & -4.540 & -4.612 \\
InLiberaldemokrasi & -3.795 & -4.017 & -4.391 \\
dlnFosilyakit & -3.171 & -2.823 & -3.176
\end{tabular}




$\begin{array}{llll}\text { dlnKişibaşınagelir } & -3.412 & -3.097 & -3.381 \\ \text { dlnSerbestticaret } & -3.329 & -3.523 & -3.713 \\ \text { dlnŞehirleşme } & -2.160 & -1.585 & -1.891 \\ \text { dlnYenenerji } & -5.169 & -5.208 & -5.387\end{array}$

Not: CIPS istatistiğinin kritik değerleri Pesaran (2007), tablo $2 a, 2 b$ ve $2 c^{\prime}$ den elde edilmiştir. 0.01 , 0.05, 0.10 anlamlllk değeri için kritik değerler sabitsiz model için strasıyla 1.85, -1.61, -1.49, sabitli model için $-2.51,-2.25,-2.12$, sabitli ve trendli model için $-3.30,-2.94,-2.76$ olarak belirlenmiştir.

Tablo 9'da durağan olan serbestticaret değişkeni dişında tüm değişkenlerin birincil farkları alınmış ve şehirleşme değişkeni dışında tüm değişkenlerin $0.01,0.05$ ve 0.10 anlamlılık düzeyinde durağan olduğu saptanmıştır. Şehirleşme değişkeninin ikinci farkı alındığında seri durağan hale gelmiştir. $\mathrm{Bu}$ durumda serbest ticaret ve doğrudan yatırım değişkenleri I(0) ve şehirleşme değişkeni I(2) ve diğer değişkenler ise I(1) entegre derecesine sahiptir. Serilerin entegre derecesindeki farklılıklar ve panel verinin zaman boyutunun birim sayısından yüksek olması gibi seriye özgü yapısal özellikler nedeni ile Görünürde İlişkisiz Regresyon (GİR) tahmincisinin kullanılması uygun görülmüştür.

\section{GİR Tahmincisi Bulguları}

Merkezi ve Doğu Avrupa ülkeleri üzerine uygulanacak modelde serilerin birim kök içermesi ve entegre derecelerinin farklı olmasının yanı sıra ilgili ülkelerin sekiz tanesinin 2004 yılı sonrasında $A B$ üyesi olması nedeni ile ortaya çıkan yapısal değişimleri bertaraf etmek amacı ile seri 1995-2005 ve 2005-2018 yılları olmak üzere iki ayrı döneme ayrıştırılarak uygulama yapılmıştır. Fakat GIR tahmincisi öncesi 1995-2018 yılları için serinin grafiğinin incelenmesinde yarar görülmüştür; bu incelemede serilerin birinci farkları alınarak durağanlaştırılmıştır.

Grafik 1'de üst panelde karbon emisyonu-gelir ilişkisi alt panel de ise seragazı emisyonu ve gelir ilişkisine yer verilmiştir. Grafikte ÇKE hipotezi dikkate alınarak $\operatorname{lnCo2fuel~ve~lnSeragazı~değişkenleri~ile~gelir~arasındaki~ilişki~}$ hem doğrusal hem de ikinci derece polinom özelliğini dikkate alarak tahmin edilmiş ve aradaki farkın ortaya çıkarılabilmesi için aynı grafik üzerinde gösterilmiştir. Grafikte eğriye ait eğimin zaman içerisinde değişim gösterdiği izlenmektedir. Bu bakımdan ekonomik gelişme düzeyi ve üretim yapısı ile 
birlikte siyasal rejimi de değişen ülkelerin durumunun $\mathrm{AB}$ üyelik sürecinde dikkate alınarak iki alt dönemde incelemenin yararlı olacağı görülmektedir.

Grafik 1'de üst panelde karbon alt panelde seragazı emisyonu söz konusu olduğunda ÇKE hipotezinin tüm ülkeler içinde geçerli olmamakla birlikte serinin bir kısmı için geçerli olduğu grafikten de izlenmektedir.

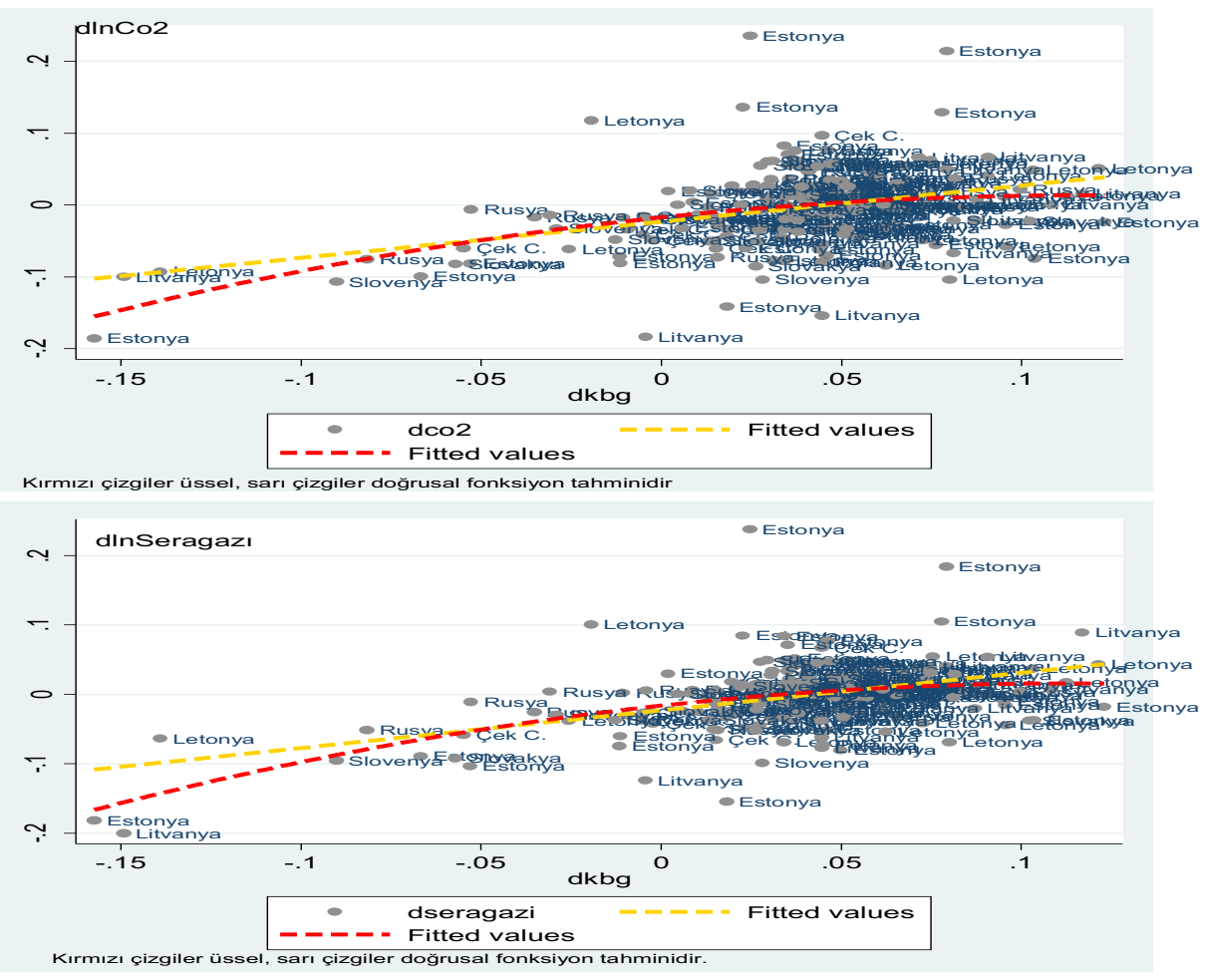

Grafik 1. InCo2fuel( InSeragazı) -Gelir İlişkisi (1995-2018)

Tablo 10. 1995-2005 Yilları için GİR Tahmin Sonuçları 


\begin{tabular}{|c|c|c|c|c|c|c|c|c|c|c|c|}
\hline & & lnkisibgelir & Inkisibgelir2 & Inserbestutic & lnyenenerji & Infosily & Inlibdem & Inşehirleşme & dy & sabit & R2 \\
\hline \multirow{9}{*}{ 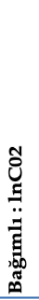 } & Çek C. & $0.992^{* * *}$ & $-0.034^{* * *}$ & $-0.631^{* * *}$ & $-0.415^{* * *}$ & 0.022 & 0.332 & . & 0.005 & - & 0.936 \\
\hline & Estonya & $1.406^{* * *}$ & $-0.058^{* * *}$ & $-1.107^{* * *}$ & $-0.162^{* * *}$ & -0.012 & -0.242 & - & 0.003 & - & 0.665 \\
\hline & Macaristan & $-1.479 * * *$ & $0.071^{* * *}$ & 0.016 & $0.125^{* * *}$ & $2.658^{* * *}$ & -0.007 & - & $0.054)^{* * *}$ & - & 0.335 \\
\hline & Letonya & $-3.440^{* * *}$ & $0.187^{* * *}$ & $-0.172^{* * *}$ & $-0.424^{* * *}$ & $4.650^{* * *}$ & -0.654 & - & 0.018 & - & 0.822 \\
\hline & Litvanya & $0.044^{* * *}$ & $-0.375^{* * *}$ & $-0.061^{* *}$ & $-0.818^{* * *}$ & $0.847^{* * *}$ & $-0655^{* * *}$ & - & $-0.042^{* * *}$ & - & 0.9887 \\
\hline & Polonya & $33.241^{* * *}$ & $-1.737^{* * *}$ & $0.104^{* *}$ & $-0.876^{* * *}$ & $-8.438^{* * *}$ & $1.35^{* * *}$ & - & 0.000 & $-28.8^{* * *}$ & 0.971 \\
\hline & Rusya & $6.246^{* * *}$ & $-0.245^{* * *}$ & $-0.124^{* * *}$ & 0.044 & $-6.718^{* * *}$ & $1.04^{* * *}$ & - & $-0.046^{* * *}$ & $\cdot$ & -1.246 \\
\hline & Slovakya & $0.416^{* * *}$ & $-0.022^{* * *}$ & $0.132^{* * *}$ & $-0.015^{* * *}$ & $0.303^{* * *}$ & $-0.110^{* * *}$ & - & $-0.016^{* * *}$ & - & 0.972 \\
\hline & Slovenya & $-1.440^{* * *}$ & $0.863^{* * *}$ & 0.066 & $0.138^{* * *}$ & $2.256^{* * *}$ & $-0.712^{* * *}$ & - & $0.044^{* * *}$ & - & 0.504 \\
\hline \multirow{9}{*}{ 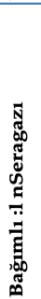 } & Çek C. & $-5.676^{* * *}$ & $0.299^{* * *}$ & $-0.658^{* * *}$ & $-0.164^{* * *}$ & -0.042 & $1.006^{* * *}$ & $9.71^{* * *}$ & $0.012^{* *}$ & - & 0.976 \\
\hline & Estonya & $3.16^{* * *}$ & $-0.160^{* * * *}$ & $-1.491^{* * *}$ & $-0.100^{*}$ & 0.063 & 0.236 & - & $0.074^{* * *}$ & - & 0.835 \\
\hline & Macaristan & $1.558^{* * *}$ & $-0.063^{* *}$ & $-0.291 * * *$ & $-0.103^{* * *}$ & 0.0524 & $-0.423^{* * *}$ & 0.892 & $0.026^{*}$ & - & 0.073 \\
\hline & Letonya & $-10.57^{* * *}$ & $0.560^{* * *}$ & 0.066 & 0.065 & $-2.838^{* *}$ & $-1.653^{* * *}$ & $17.533^{* * *}$ & $-0.086^{* *}$ & - & 0.832 \\
\hline & Litvanya & $1.548^{* * *}$ & $-0.061^{* * *}$ & -0.026 & $-0.518^{* * *}$ & $0.477^{* * *}$ & $-0.540^{* * *}$ & - & $0.037^{* * *}$ & - & 0.956 \\
\hline & Polonya & $20.054^{* * *}$ & $-1.056^{* * *}$ & $0.087^{* * *}$ & $-0.665^{* * *}$ & 1.723 & $2.046^{* * *}$ & $-23.135^{* * *}$ & $0.020^{* * *}$ & - & 0.988 \\
\hline & Rusya & $0.601^{* * *}$ & -0.0117 & $0.0845^{* * *}$ & $0.309^{* * *}$ & $2.202^{* * *}$ & $0.081^{* * *}$ & - & 0.003 & & 0.814 \\
\hline & Slovakya & $-18.31^{* * *}$ & $0.989^{* * *}$ & -0.205 & $0.149^{* * *}$ & 0.334 & -0.042 & $24.140 * * *$ & $-0.009 * * *$ & -2.192 & 0.830 \\
\hline & Slovenya & $-6.710^{* * *}$ & $0.329^{* * *}$ & $-0.314^{* * *}$ & $0.323^{* * *}$ & $1.138^{* * *}$ & $1.152^{* * *}$ & $9.692^{* * *}$ & $0.0217^{* * *}$ & - & 0.954 \\
\hline
\end{tabular}

Tablo 10'da 1995-2005 yılları için GİR tahmin sonuçları sunulmaktadır. Buna göre lnCo2fuel'in bağımlı değişken olarak kullanıldığı ilk modelde Çek Cumhuriyeti, Estonya, Litvanya, Polonya, Rusya ve Slovakya için gelir değişkeni pozitif gelirin karesi negatif işarete sahiptir; ÇKE hipotezi geçerlidir. Benzer şekilde lnSeragazı bağımlı değişken olarak tercih edildiği ikinci modelde Estonya, Macaristan ( $R^{2}$ düşük olduğu için model anlamsızdır), Litvanya ve Polonya içinde ilgili dönemde ÇKE hipotezi geçerli görünmektedir. Birinci model incelendiğinde ilgili dönemde Polonya ve Slovakya ülkeleri dışında diğer ülkelerde karbon emisyonu ve serbest ticaret arasında negatif ilişki görülmesinin ekonominin istikrar kazanma süreci ve piyasa kurumlarının tam olarak işlevsel hale gelmemesi ile birlikte büyümeye katkı sunmaması ile ilişkili olduğu düşünülmektedir. Aynı dönemde Çek Cumhuriyeti, Estonya, Letonya, Litvanya, Polonya ve Slovakya'da yenilenebilir enerji ile karbon emisyonu arasında negatif ilişki görülmekte; Macaristan, Litvanya, Letonya, Slovenya ve Slovakya'da fosil yakıt kullanımı ve karbon emisyonu arasında pozitif ilişki olduğu tespit edilmektedir. Merkezi planlamacı otoriter rejim sonrası demokratik kurumların yeni tesis edilmeye başlandığı ilgili dönemde Litvanya, Slovenya ve Slovakya'da karbon emisyonu ile demokratik kurumlar arasında negatif yönlü ilişkinin olduğu görülmektedir. Çek Cumhuriyeti, Estonya, Letonya, Litvanya ve Rusya ülkesi için doğrudan yatırımlar ile 
karbon emisyonu arasında negatif yönlü ilişki varken, Polonya ve Alovakya' da pozitif yönlü ilişki mevcuttur. Breusch-Pagan testi ülkeler arasında korelasyon olduğunu doğrulamaktadır.

1995-2005 dönemi için ikinci modelde ise Çek Cumhuriyeti, Estonya, Macaristan ve Slovenya arasında serbest ticaret ve seragazı emisyonu arasında negatif ilişki saptanmıştır. Çek Cumhuriyeti, Letonya, Slovakya ve Slovenya'da da seragazı emisyonu ve gelir arasında negatif ilişki mevcutken Estonya, Macaristan, Litvanya, Polonya ve Rusya arasında pozitif yönlü bir ilişki saptanmıştır. Litvanya, Slovenya ve Rusya'da fosil yakıt kullanımı ve seragazı emisyonu arasında pozitif yönlü ilişki belirlenmiştir. Macaristan, Letonya ve Litvanya' da demokratik kurumlar ve seragazı emisyonu arasında negatif yönlü ilişki mevcuttur. Litvanya, Rusya ve Slovenya'da sera gazı emisyonu ve şehirleşme aynı yönde hareket etmektedir. Çek Cumhuriyeti, Estonya, Macaristan ve Slovenya'da doğrudan yatırımlar ile seragazı emisyonu arasında pozitif yönlü ilişki vardır. Breusch Pagan testi ülkeler arasındaki korelasyonu teyit etmektedir.

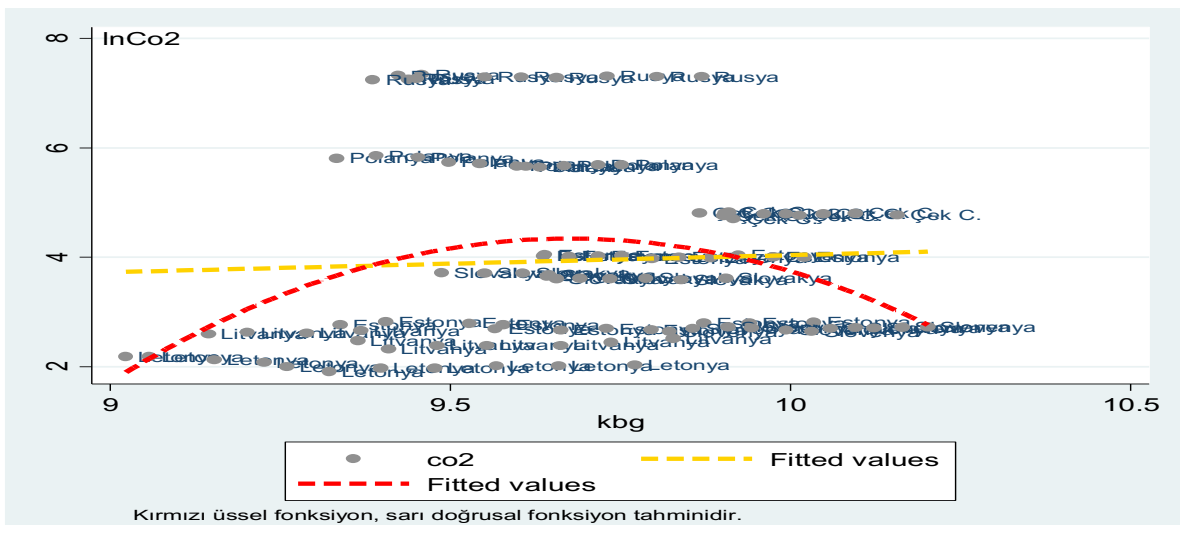


Demokrasi ve Yenilenebilir Enerjinin Çevre Kirliliği Üzerine Etkisi: Görünürde İlişkisiz Regresyon Analizi

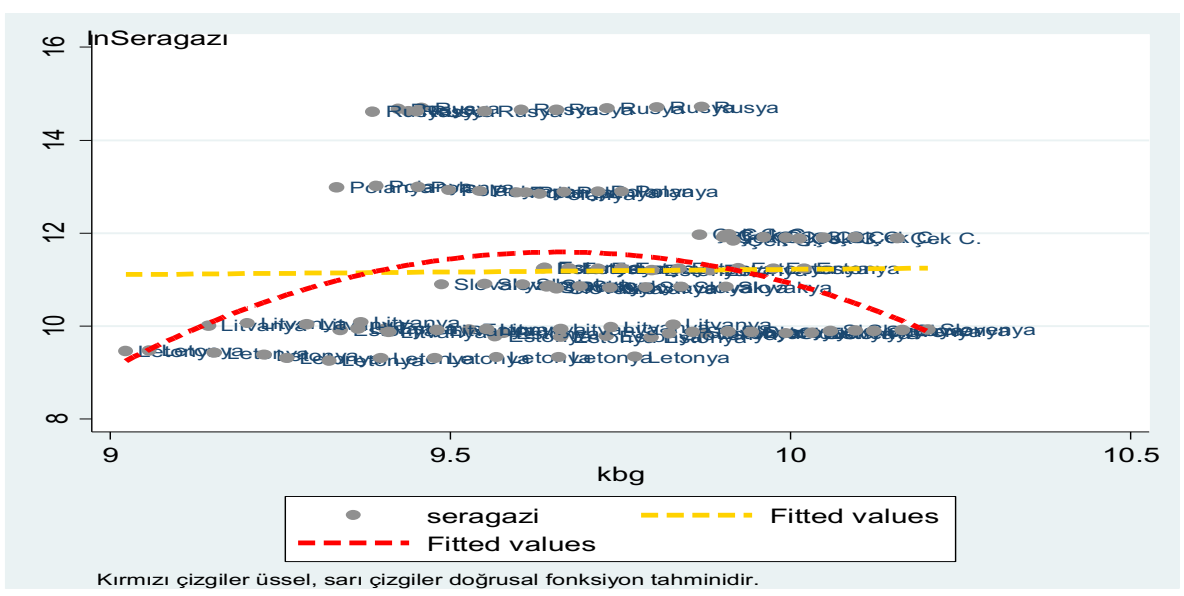

\section{Grafik2. 1995-2005 Yıllan lnCo2fuel(lnSerazı) -Gelir İlişkisi}

Grafik 2 incelendiğinde $\mathrm{AB}$ üyelik sonrası karbon (seragazı) emisyonu ile gelir arasındaki ters U ilişkisinin devam ettiği fakat 1995-2005 yıllarında olduğu kadar güçlü olmadığ görülmektedir. Bu durumun ilk dönem ekonomik büyümenin kazandığg ivmenin ikinci döneme kıyasla daha yüksek olmasından kaynakladığı düşünülmektedir.

Tablo 11. 2005-2018 Yılları için GİR Tahmin Sonuçlan

\begin{tabular}{|c|c|c|c|c|c|c|c|c|c|c|}
\hline & Inkisibgelir & Inkisibgelir2 & Inserbestutic & lnyenenerji & Infosily & Inlibdem & Inşehirleşme & dy & sabit & R2 \\
\hline Çek C. & $11.407^{* * *}$ & $-0.544^{* * *}$ & -0.355 & $-0.228^{* * *}$ & $0.859^{* * * *}$ & $-0.29 * * *$ & $-13.517^{* * *}$ & $0.008^{* * *}$ & - & 0.997 \\
\hline Estonya & 1.717 & -0.1010 & $4.124^{* * *}$ & $-1.028^{* * *}$ & $-0.40^{* * *}$ & -1.038 & -4.469 & 0.021 & - & 0.595 \\
\hline Macaristan & -2.397 & $-2.397^{* * *}$ & -0.0718 & $0.499^{* *}$ & $3.239^{* * *}$ & $0.466^{* * *}$ & -1.470 & $-0.025^{* *}$ & - & 0.983 \\
\hline Letonya & $-23.84^{* * *}$ & $1.196^{* * *}$ & $0.827 * * *$ & $-0.341^{* *}$ & $0.620^{* * * *}$ & $-0.327^{*}$ & $27.406^{* * *}$ & $0.012^{*}$ & - & 0.910 \\
\hline Litvanya & $-20.143^{* * *}$ & $0.977^{* * *}$ & $0.9017^{* *}$ & $-0.380^{* * *}$ & $0.462^{* * *}$ & $1.151^{* * *}$ & $23.323^{* * *}$ & $0.016^{* * *}$ & - & 0.919 \\
\hline Polonya & $-33.588^{* *}$ & $1.701^{* *}$ & $1.447^{* *}$ & $0.282^{* * *}$ & $3.023^{* *}$ & $-0.133^{* *}$ & $15.086^{* * *}$ & -0.004 & 89.65 & 0.806 \\
\hline Rusya & -4.017 & 0.230 & $-0.152^{* * *}$ & $-0.266^{* * *}$ & $1.746^{* * *}$ & -0.004 & $-35.506^{* * *}$ & $0.010^{* *}$ & 168.23 & 0.947 \\
\hline Slovakya & $-15.754^{* *}$ & $0.077^{* *}$ & $0.281^{*}$ & $-0.317^{* * *}$ & $2.337^{* * *}$ & -0.200 & $-9.830^{* * *}$ & 0.003 & 112.22 & 0.985 \\
\hline Slovenya & 1.090 & 0.120 & -0.432 & -0.004 & $0.686^{* *}$ & $0.784^{* * *}$ & $-3.108^{* * *}$ & $-0.03^{* * *}$ & - & 0.932 \\
\hline Çek C. & $9.777^{* * *}$ & $-0.463^{* * *}$ & -0.042 & $-0.214^{* * *}$ & $0.579^{* * *}$ & $-0.26^{* * *}$ & $-9.674^{* * *}$ & $0.003^{* *}$ & - & 0.996 \\
\hline Estonya & 7.342 & -0.354 & $4.066^{* * * *}$ & $-1.047^{* * *}$ & $-0.41^{* * *}$ & -2.290 & $-10.458^{* * *}$ & $0.063^{* *}$ & - & 0.605 \\
\hline Macaristan & 1.544 & -0.0325 & -0.079 & 0.157 & $1.671^{* * *}$ & 0.165 & -1.947 & $-0.021^{* *}$ & - & 0.973 \\
\hline Letonya & $14.88^{* * *}$ & $0.744^{* * *}$ & $1.199^{* * *}$ & $-0.251^{* * *}$ & $0.307^{* * *}$ & -0.1143 & $18.403^{* * *}$ & 0.003 & & 0.855 \\
\hline Litvanya & 0.743 & -0.027 & $1.045^{* * *}$ & $-0.360^{* * *}$ & $-0.36^{* * *}$ & 0.146 & 0.134 & $0.026^{* * *}$ & & 0.976 \\
\hline Polonya & -16.572 & 0.840 & $1.278^{* *}$ & 0.129 & $2.219^{* *}$ & $-0.104^{*}$ & $7.493^{*}$ & -0.000 & 48.30 & 0.699 \\
\hline Rusya & $7.547^{* * *}$ & $-0.363^{* * *}$ & $-0.066^{* * *}$ & $-0.172^{* * *}$ & $0.751^{* * *}$ & 0.0135 & $-6.579^{* * *}$ & $0.007^{* * *}$ & - & 0.899 \\
\hline Slovakya & $2.70 \% * * *$ & $-0.134^{* * *}$ & 0.098 & $-0.200^{* * *}$ & $1.161^{* * *}$ & -0.823 & $-2.053^{*}$ & $0.011^{* * *+}$ & - & 0.992 \\
\hline Slovenya & $1.818^{* * * *}$ & $-0.053^{* * *}$ & -0.404 & $-0.089^{* *}$ & $0.826^{* * *}$ & 0.350 & $-1.386^{* *}$ & $-0.01 * * *$ & - & 0.9654 \\
\hline
\end{tabular}


Tablo 11'de 2005-2018 yılları için GİR tahmin sonuçları sunulmaktadır. 20052018 döneminde Rusya hariç ilgili ülkelerin tamamı AB üyesi olmuştur. $\mathrm{Bu}$ durumda karbon emisyonu gelir ilişkisinin incelendiği birinci modelde Çek Cumhuriyeti için; sera gazı emisyonun gelir ile ilişkisinin ele alındığı ikinci model de Çek Cumhuriyeti, Rusya, Slovenya ve Slovakya'da gelir ve gelirin karesinin anlamlı olmalarına bağlı olarak ÇKE hipotezinin geçerli olduğu sonucuna ulaşılabilmektedir.

Serbest ticaretin karbon emisyonu ile pozitif ilişki gösterdiği ülkeler ise Estonya, Polonya, Litvanya, Letonya ve Slovakya'dır. Çek Cumhuriyeti, Estonya, Letonya, Litvanya, Rusya ve Slovakya'da yenilenebilir enerji kaynaklarının kullanılması karbon emisyonu ile negatif ilişki içinde görülmektedir. Fakat fosil yakıt kullanımı ile karbon emisyonu arasında negatif ilişki yalnızca Estonya' da sağlanmaktadır. Demokratik kurumların varlığ 1 Çek Cumhuriyeti, Letonya ve Polonya'da karbon emisyonunın azalmasına neden olmuştur. Şehirleşme Letonya, Litvanya ve Polonya'da karbon emisyonunın artışına neden olmaktadır. Doğrudan yatırımlar ise Rusya' da karbon emisyonuyla negatif yönlü ilişkiye sahiptir. Bağımlı değişken olarak serazgazının kullanıldığ 1 ikinci modelde ise Çek Cumhuriyeti, Rusya, Slovenya ve Slovakya için ÇKE hipotezinin geçerli olduğu sonucuna ulaşılmaktadır. Serbest ticaret Estonya, Letonya, Litvanya ve Polonya ülkelerinde sera gazı emisyonu ile pozitif yönlü; Rusya da negatif yönlü ilişki göstermektedir. Yenilenebilir enerji kaynakları Çek Cumhuriyeti, Estonya, Letonya, Litvanya, Rusya, Slovakya ve Slovenya'da seragazı emisyonu ile negatif ilişki göstermektedir. Fakat Estonya ve Litvanya hariç diğer ülkelerde fosil yakıt kullanımı ve seragazı emisyonu arasında pozitif yönlü ilişki mevcuttur. Liberal demokrasi Çek Cumhuriyeti ve Polonya'da seragazı emisyonu ile negatif ilişki içindedir. Şehirleşme Letonya ve Polonya'da seragazı emisyonu ile pozitif ilişki içindedir. Estonya, Letonya, Litvanya ve Polonya ülkelerinde de doğrudan yatırımlar ve seragazı emisyonu arasında pozitif yönlü ilişki vardır.

2005-2018 yılları için ÇKE hipotezinin geçerli olup olmadığının irdelendiği Grafik 3'te, 1995-2005 yıllarına kıyasla karbon emisyonu ve gelir arasındaki ilişkinin daha zayıf olduğu görülmektedir. Bu ilk dönem için geçerli olan büyüme ivmesinin ikinci dönemde yavaşlaması ile de değerlendirilebilir. 
Demokrasi ve Yenilenebilir Enerjinin Çevre Kirliliği Üzerine Etkisi: Görünürde İlişkisiz Regresyon Analizi

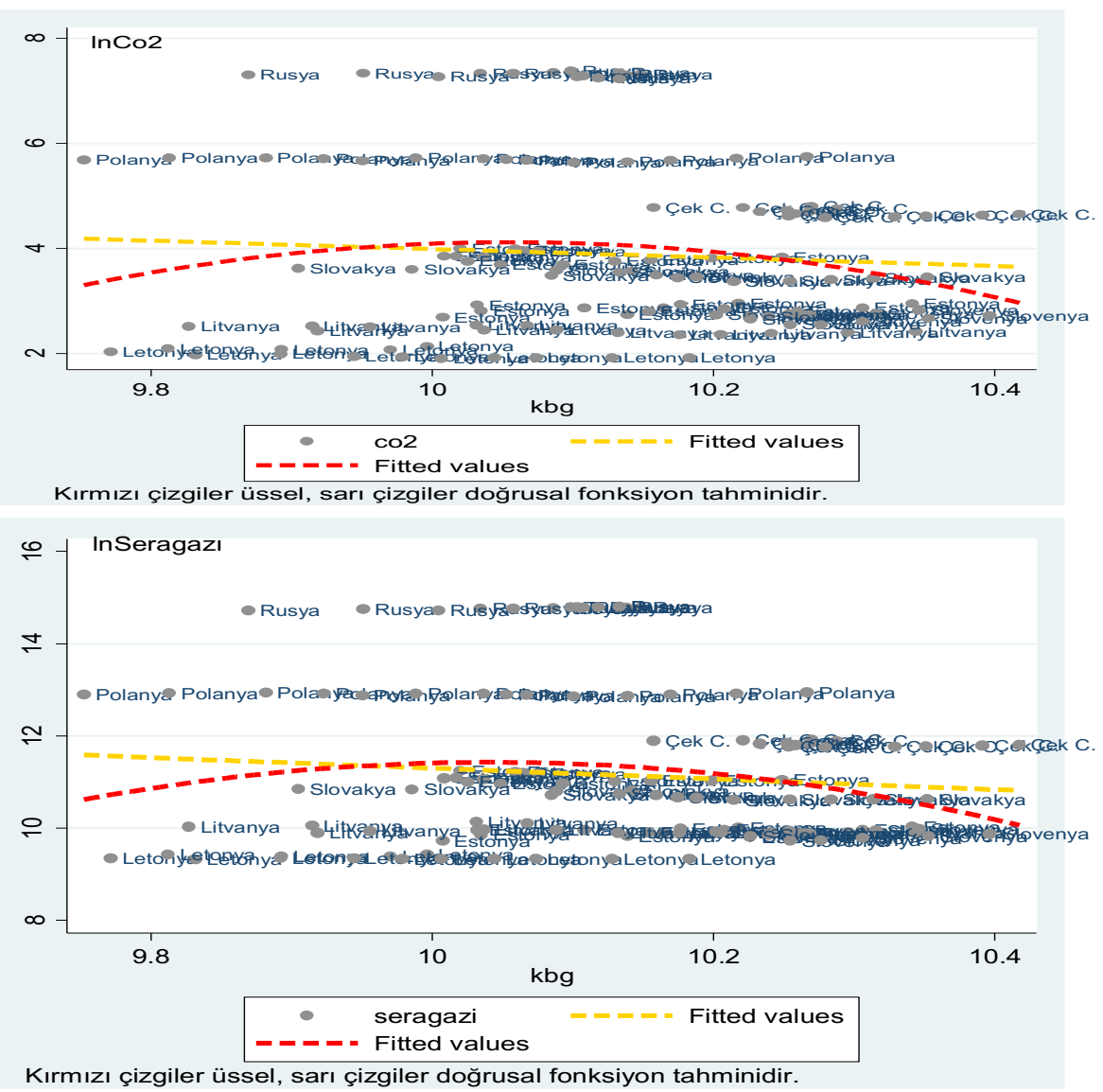

Grafik 3. 2005-2018 Yılları lnCo2fuel(lnSerazı) -Gelir İlişkisi

1995-2005 ile 2005-2018 yıları kıyaslandığında Çek Cumhuriyeti'nde demokrasinin karbon emisyonu ile ilk dönem pozitif yönlü olan karbon emisyonu üzerindeki etkisinin 2005-2018 döneminde negatif yönlü hale geldiği görülmektedir. Yenilenebilir enerji kaynakları bakımından ise ilk dönem karbon emisyonu ile negatif yönlü ilişkiye sahip olunan Polonya'da ikinci dönem bu ilişkinin pozitif yönlü hale geldiği görülmektedir.

Bu sonuçlar literatürde MDAÜ üzerine odaklanan bir grup çalışmadan farklılaşmaktadır. Destek, Ballı ve Manga (2011), MDAÜ üzerine 1991-2011 yılları için yaptıkları incelemede ÇKE hipotezinin geçerli olduğu sonucuna ulaşmışlar, enerji tüketimi ve ticari açıklığın karbon emisyonunu arttırdığını 
göstermişlerdir. Fakat GİR tahmincisi bir grup ülke için geçerli olan sonucun tüm MDAÜ için aynı olamayabileceğini göstermektedir. İlgili çalışmada şehirleşme düzeyinin karbon emisyonu üzerindeki etkisinin belirsiz olması, yaptığımız analiz sonuçları ile paralellik sergilemektedir. Ho ve Iyke (2019) ise ticari açıklığın uzun dönemde belirli bir eşik değerinden sonra ancak karbon emisyonunu azalttı̆ı̆ı göstermektedir. Bu GİR tahmininde serbest ticaretin etkisinin ülkeler arasında neden farklılaştığının da bir göstergesi olabilir. Nitekim ülkelerin ticari açıklı ile birlikte serbest ticarette edindikleri başarı düzeyi de farklılaşmaktadır. Ho vd. (2019) MDAÜ ‘de ÇKE hipotezininde uzun dönem için geçerli olduğu sonucuna ulaşmışlardır. Li vd.(2020) ise 1996-2018 dönemini ele aldığ çalışmasında Slovakya' daki çevre kalitesindeki iyileşmeyi desteklemektedir. Zira GİR tahmini 2005-2018 yılları için seragazı emisyonu bağımlı değişkeninde Slovakya için ÇKE hipotezinin geçerli olduğunu göstermektedir. Ülkelerin ilgili dönemlerde sektörel yapılarının farklılaşması (sanayi, tarım, ormancılık, yüksek teknolojili ürünler vb.) ticari açıllık, doğrudan yatırımlar gibi bir dizi faktörün çevre kalitesi ve karbon (seragazı) emisyonu üzerinde farklı etkiler yaratmasının da nedeni olabileceği Liv vd. (2020) sonuçlarından izlenebilmektedir. Doğrudan yabancı yatırımların hızlı ekonomik büyümenin kaynağı olmakla birlikte enerji kaynaklarının kullanımı (fosil yakıtlar veya yenilenebilir enerji) ile AB enerji politikasına erişimin çevre kalitesi üzerindeki etkisinin belirsiz olduğu bulgusuna ulaşmışlardır. Bu durum, GİR tahmin sonuçlarında ülkeler tek tek incelendiğinde ortaya çkan bazı tutarsız sonuçlarla benzer bir görünüm sergilemektdir. Nüfus artısı değişkeni ilgili çalışmada istatistiksel olarak anlamlı bir sonuç vermemiş, benzer bulgu şehirleşme açısından bakıldığında GİR sonuçlarında da görülmektedir.

GIR tahmininde kullanılan demokrasi değişkeni ise diğer çalışmalarda yer bulmamıştır. Demokratik kurumların varlığı, ekonominin istikrar kazanması, kapsayıcı ekonomik gelişme, teknolojik ilerlemenin önemli bir bileşeni olarak kabul edilmektedir (Özdemir, 2015). Doğrudan yatırımların ekonomik ve siyasal istikrar kazanmış ülkelere aktığı düşünüldüğünde MDA ülkelerinin demokratikleşme düzeyinin yanı sektörel tercihler ve üretim yapısına bağlı (Çuhadar ve Doru, 2020) olarak dolaylı yoldan çevre kalitesi üzerinde etki yaratabileceği görülmektedir. Konunun sivil toplumun çevre duyarlılığ ile çevresel kalite üzerinde nasıl etki yaratacağı ise daha derinlikli sosyolojik bir çalışmanın konusudur. 


\section{Tartışma ve Sonuç}

Ekonomik faaliyetlerden kaynaklı olarak artan sera gazı salınımı çevre kalitesini olumsuz yönde etkilemektedir. Çevre kalitesinin bozulması ise küresel ısınma ve iklim değişikliği gibi tüm dünyayı ilgilendiren çevresel sorunlara yol açmaktadır. Çevresel sorunları önleyebilmek adına ülkeler bir taraftan çevre politikaları geliştirmekte bir taraftan da uluslararası anlaşmalara ayak uydurmaktadırlar. Çevre kirliliği gelir, enerji tüketimi, kentleşme, doğrudan yabancı sermaye yatırımları, dış ticaret ve ülkelerin demokratikleşme düzeyi gibi pek çok faktöre bağlı olarak ortaya çıkmaktadır.

Bu çalışmada demokrasi ve yenilenebilir enerjinin çevre kalitesine etkisi Görünürde İlişkisiz Regresyon (GİR) ile Merkezi ve Doğu Avrupa ülkelerinde 1995-2018 dönemi için analiz edilmiştir. Bu yöntem zaman boyutunun birim sayısından büyük olduğu, birbiri ile yüksek korelasyona sahip birimlerin bulunduğu panel veri için uygun bir yöntem olduğundan tercih edilmiştir. Karbon ve seragazı emisyonunun ayrı ayrı bağımlı değişken olarak kullanıldığı modellerde ilgili yıllar, alt dönemlere ayrıştırılarak inceleme yapılmış; AB üyelik süreci ile birlikte ekonomik ve siyasal kurumlarda ortaya çkan değişimin de etkisi analiz edilmek istenmiştir.

GİR tahmin sonuçları, ÇKE hipotezinin tüm ülkeler için geçerli olmadığını, bu farklılaşmada ülkeler arasında ticarete konu olan sektörlerin ve gelen doğrudan yatırımların üretim alanlarının önemli bir etken olduğu görülmüştür. Fakat, $\mathrm{AB}$ üyelik süreci sonrası $\mathrm{AB}$ 'nin yenilenebilir enerji kaynaklarına yoğunlaşması ve karbonsuzlaşma hedefi doğrultusunda (Cemek ve Çuhadar, 2020) birçok ülkede yenilenebilir enerji kullanımı yaygınlaştırılmaya çalışılsa da, Macaristan ve Polonya'da Birlik Üyeliği sonrası karbon emisyonu ve yenilenebilir enerji arasında pozitif yönlü ilişkinin mevcut olduğu da dikkatten kaçmamalıdır. Dolayısıyla Birlik üyeliği tüm ülkelerde benzer sonuçlar ortaya çıkarmamıştır. Yenilenebilir enerji kullanımının 1995-2003 döneminde birçok ülkede karbon emisyonu ile halihazırda negatif ilişki göstermeside $\mathrm{AB}$ üyeliğinin ülkelerin tamamından gözle görülür açık bir değişim yaratmadığ sonucunu desteklemektedir.

Bu bulgular önemli politika çıkarımları ortaya koymaktadır. Ampirik bulgular serbest ticaretin Merkezi ve Doğu Avrupa ülkelerinde $\mathrm{CO}_{2}$ emisyonu ve sera gazı salınımı üzerinde çoğunlukla artış yönünde etki yarattı̆̆ını 
göstermektedir. Bu durum, artan üretim hacminin karbon ve sera gazı emisyonunun artışına katkı sunduğu ve bu konudaki kurumsal düzenlemelerin yetersiz kaldığını göstermektedir. Dolayısıyla, Merkezi ve Doğu Avrupa ülkeleri yenilenebilir enerjiye yatırımlarını ülkelere yaymalıdır ve çevre kalitesindeki kurumsal düzenlemeler daha işlevsel hale getirilmelidir. Ayrıca, bu çalışmada demokrasinin çevresel kirlilik göstergelerini kimi ülkelerde azalttığ 1 da görülmüş olmakla birlikte demokrasinin çevresel kaliteyi iyileştiren bir faktör olduğunu tüm ülkeler için doğrulanamamaktadır. Bu sonucun demokratik teamüllerin uygulamalara yansımasındaki farklılıklardan daha açık ifade ile demokrasinin niteliğinden kaynaklanabileceği düşünülmektedir. Bu nedenle ülkelerin demokrasi düzeyinin yükselmesi karbon emisyonunun azaltılması açısından hangi koşullarda faydalı olacağı, hangi kurumsal düzenlemelerin etkili sonuçlar çıkaracağı da ele alınması tartışılması gereken bir konu olarak karşımıza çıkmaktadır. Bu noktada yapılan çıarsama gelecekte yapılacak araştırmalara da yantlanması gereken önemli bir soru bırakmaktadır. 


\title{
Democracy, Renewable Energy and Environmental Pollution Relation: Seemingly Unrelated Regression
}

\author{
Melike Atay Polat- Pınar Çuhadar \\ Mardin Artuklu University
}

The impacts of greenhouse gases and carbon emissions on climate change and global warming as a result of human economic activities have caused researchers and policy makers to heavily discuss the topic of environmental quality in recent years. The first researches on environmental quality focused on explaining the relationship between environmental degradation and income. Within that context, the environmental Kuznets curve (EKC) hypothesis was created, which suggests that a country's environmental degradation increases when its income per capita is low, while its environmental degradation decreases when its economy develops (inverted-U relationship). However, environmental pollution is not only related to income level. Various socio-economic indicators such as energy use, urbanisation, international trade, and foreign capital investments have substantial impacts on the environment. In recent years, whether the process of democratisation and using renewable energy sources have an effect on environmental quality or not has also become a discussion topic. In contrast to the extensive literature about economic growth's impact on environmental degradation, there is a limited number of empirical studies that examine the impact of democracy and renewable energy on environmental quality in developing countries. Furthermore, examining the effect of democratic institutional structure and the use of renewable energy sources on environmental quality gains importance in terms of questioning the effect of institutional arrangements and renewable energy investments.

\section{Purpose}


This study focuses on Central and Eastern European countries (Czech Republic, Estonia, Hungary, Lithuania, Latvia, Poland, Russia, Slovakia, Slovenia), who have transitioned from centrally planned economy into market economy and have gone through structural and institutional changes, and where renewable energy holds an ever-increasing place within total energy consumption; in short, countries who have similar political-economic models and energy structures. The main contribution of the study is that it examines the relationship between renewable energy, environmental degradation and democracy for this group of countries as well as discussing the relationship between democracy and environment based on different environmental pollution types and offering the opportunity to compare empirical results. In addition, the hypothesis that renewable energy improves environmental quality is tested in the study, and the study aims to find results that support the EKC hypothesis using different models and methods. Moreover, while the method used reveals the EKC results for each country, the general situation of the panel data has also been tried to be revealed by graphs.

\section{Methods}

In the study, the validity of the environmental Kuznets curve (EKC) hypothesis, and its relationship with democracy and renewable energy is put to test for nine Central and Eastern European countries (Czech Republic, Estonia, Hungary, Lithuania, Latvia, Poland, Russia, Slovakia and Slovenia) that have completed their transition periods. Before econometric estimation, homogeneity and cross section dependence test, panel unit root tests are implemented respectively, then SUR estimator is used for checking EKC hypothesis validity. Moreover, graphical representation is used for checking whether $U$-shape or inverse $U$-shape is valid for across the panel data.

\section{Findings}


SUR estimation results supports that the EKC hypothesis is not valid for all countries. The literature review shows that the trade between countries and the production areas of foreign direct investments are important factors in this differentiation. The use of renewable energy has been tried to be expanded in many countries rest upon EU's energy policy and decarbonization target, there is a positive relationship between carbon emission and renewable energy in a few countries such as Hungary and Poland after being Union's member. Hence, being member of the Union has not produced similar results in all countries.

The democracy variable used in SUR estimator is not included in other studies. It is well accepted in economics literature that the existence of democratic institutions have positive impact on stabilization and development level of the economy. It is seen that democratic quality is not homogenous in all CCE countries and democracy have indirect impact on environmental quality of CCE countries related with foreign direct foreign investments.

\section{Conclusion}

Empirical findings show that market based free trade cause negative effect on $\mathrm{CO} 2$ emissions and greenhouse gas emissions in Central and Eastern European countries. This shows that the increased production volume contributes to the increase in carbon and greenhouse gas emissions and that the institutional arrangements in this regard are insufficient for these countries. Therefore, Central and Eastern European countries should make more investment in renewable energy and institutional arrangements on environmental quality should apply more effectively. Moreover, it cannot be confirmed for all countries that democracy improves environmental quality, so there are differences in quality of democratic instutions and its environmental effect for CCE countries.

\section{Kaynakça / References}


Adams, S. and Acheampong, A.O. (2019). Reducing carbon emissions: The role of renewable energy and democracy. Journal of Cleaner Production, 240, 1-13.

Adams, S. and Klobodu, E.K.M. (2017). Urbanization, democracy, bureaucratic quality and environmental degradation. Journal of Policy Modeling, 39(6), 1-30.

Akın, C.S. (2014). Kurumsal kalitenin çevre üzerine olan etkileri: BRICS ülkeleri üzerine bir uygulama. Uluslar arası Alanya İşletme Fakültesi Dergisi, 6(2), 1-8.

Archibald, S. O., Bochniarz, Z., Gemma, M. and Srebotnjak, T. (2009). Transition and sustainability: empirical analysis of environmental Kuznets Curve for water pollution in 25 countries in central and eastern Europe and the commonwealth of independent states. Environmental Policy and Governance, 19(2), 73-9.

Arvin, M. and Lew, B. (2011). Does democracy affect environmental quality in developing countries?. Applied Economics, 43(9), 1151-1160.

Aslan, A., Altinoz, B. ve Atay Polat, M. (2020). The nexus among climate change, economic growth, foreign direct investments, and financial development: $\mathrm{New}$ evidence from N-11 countries. Environmental Progress \& Sustainable Energy, 40(3), 1-9.

Aticl, C. (2009). Carbon emissions in Central And Eastern Europe: Environmental Kuznets Curve and implications for sustainable development. Sustainable Development, 17(3), 155-160.

Bättig, M. and Bernauer, T. (2009). National institutions and global public goods: Are democracies more cooperative in climate change policy? International Organization, 63(2), 281-308.

Brien, S., Swalem, B. and MacDowall , A.(2019). Central and Eastern Europe prosperity report the lived experience. Legatum Institute, $\mathrm{UK}$.

Cemek, E. ve Çuhadar, P. (2020). İklim değişikliği ile mücadelede teknoloji yatırmmlarmn rolü: AB ülkeleri üzerine bir inceleme içinde yeni eko-tek dünya. Teknolojinin Son Sürümü. Bursa: Ekin Yayınevi.

Ćetković, L. and Buzogány, A. (2020). Between markets, politics and path-dependence: Explaining the growth of solar and wind power in six Central and Eastern European countries. Energy Policy, 139, 1-9.

Chou, C.L., Zhang, H.W., Wang, Y.M. and Yang, M.F. (2019). The influence of democracy on emissions and energy efficiency in America: New evidence from quantile regression analysis. Energy \& Environment, 31(8), 1-17.

Çuhadar, P. ve Doru, Ö. (2020). Kurumlar ve uluslararası ticaret ilişkisi: Geçiş ekonomileri üzerine panel veri analizi ile bir inceleme. Sosyoekonomi, 28(45), 165186. 
Destek, M. A., Ballı, E. ve Manga, M. (2016). The relationship between CO2 emission, energy consumption, urbanization and trade openness for selected CEECs. Research in World Economy, 7(1), 52-58.

Dinda, S. (2004). Environmental Kuznets Curve hypothesis: A survey. Ecological Economics, 49, 431-455.

Eurostat, 2019. Renewable Energy Statistics. Erişim: https://ec.europa.eu/eurostat/statistics-explained/index.php/Renewable_energy_statistics. Erişim tarihi.15.03.2020

Fredriksson, P. G. and Neumayer, N. (2013). Democracy and climate change policies: Is history important?. Ecological Economics, 95, 11-19.

Grieveson, R., Gligorov, V., Havlik, P., Hunya, G., Pindyuk, O., Podkaminer, L. and Weinberger-Vidovic, H. (2019). Looking back, looking forward: Central and Eastern Europe 30 years after the fall of the Berlin Wall (No. 4). wiiw Essays and Occasional Papers.

Grossman, G. and Kreuger A. (1991). Environmental impacts of a North American free trade agreement. NBER Working Paper, No. 3914. Erişim Tarihi: 12.12.2013. http://www.nber.org/papers/w3914.pdf.

Grossman, G. and Kreuger, A. (1995). Economic growth and the environment. The Quarterly of Journal Economics, 110(2), 353-377.

Guloglu, B. ve Ivrendi, M. (2010). Output fluctuations: Transitory or permanent? The case of Latin America. Applied Economics Letters, 17(4), 381-386.

Ho, S. Y. and Iyke, B. N. (2019). Trade openness and carbon emissions: Evidence from Central and Eastern European countries. Review of Economics, 70(1), 41-67.

Hotunluoğlu, H. ve Yılmaz, G. S. (2018). Demokrasi karbondioksit emisyonu için önemli mi? Türkiye için bir uygulama. Siyaset, Ekonomi ve Yönetim Araştırmaları Dergisi, 6(1), 133-141.

Hurlin, C. (2018). Advanced econometrics. Lecture note of school of Economics and Management - University of Geneva. 21.04.2020 tarihindehttps://www.univorleans.fr/deg/masters/ESA/CH/Geneve_Chapitre0.pdf' sitesinden alınmıştır.

Hurlin, C. ve Mignon, V. (2007). Second generation panel unit root tests. Halshs-Archive, No: 00159842, 1-25.

Iordache, I., Bouzek, K., Paidar, M., Stehlik, K., Topler, J., Stygar, M., Dabrowa, J., Brylewski, T., Stefanescu, I., Iordache, M., Schitea, D., GrigorieV, S.A., Fateev, V.N. and Zgonnik, V. (2019). The hydrogen context and vulnerabilities in the Central and Eastern European countries. International Journal of Hydrogen Energy, 44, 19036-19054. 
Jebli, M. B., Youssef, S. B. and Ozturk, İ. (2013). The Environmental Kuznets Curve: The role of renewable and non-renewable energy consumption and trade openness. MPRA Paper No. 51672, 1-18.

Jorgenson, A.K., Alekseyko, A. and Giedraitis, V. (2014). Energy consumption, human well-being and economic development in Central and Eastern European Nations: A cautionary tale of sustainability. Energy Policy, 66, 419-427.

Kashwan, P. (2017). Inequality, democracy and the environment: A cross-national analysis. Ecological Economics, 131, 139-151.

Kim, Y., Kim, S., Baek, J. and Heo, E. (2018). The linkages between democracy and the environment: Evidence from developed and developing countries. Energy \& Environment, 30(5), 1-12.

Li, R., Jiang, H., Sotnyk, I., Kubatko, O. ve Almashaqbeh Y.A, I. (2020). The CO2 emissions drivers of post-communist economies in Eastern Europe and Central Asia. Atmosphere, 11(9), 1019.

$\mathrm{Lv}, \mathrm{Z}$. (2017). The effect of democracy on CO2 emissions in emerging countries: Does the level of income matter? Renewable and Sustainable Energy Reviews, 72, 900906.

Park, H. M. (2011). Practical guides to panel data modeling: A step-by-step analysis using stata. Public Management and Policy Analysis Program, Graduate School of International Relations, International University of Japan, 12, 1-52.

Pesaran, H. (2007). Simple Panel unit root test in the presence of cross-section dependence. Journal of Applied Econometrics, 22, 265-312.

Peseran, M. and Yamagata, T. (2008). Testing slope homogeneity in large panels. Journal of Econometrics, 142(1), 50-93.

Policardo, L. (2016). Is democracy good for the environment? Quasi-experimental evidence from regime transitions. Environmental and Resource Economics, 64, 275-300.

Sadorsky, P. (2009). Renewable energy consumption, CO2 emissions and oil prices in the G7 countries. Energy Economics, 31(3), 456-462.

Sadorsky, P. (2011). Financial development and energy consumption in Central and Eastern European frontier economies. Energy Policy, 39, 999-1006.

Shafiei, S. and Salim, R. A. (2014). Non-renewable and renewable energy consumption and $\mathrm{CO} 2$ emissions in OECD countries: A comparative analysis. Energy Policy, 66, 547-556.

Solarin, S.A. and Shahbaz, M. (2015). Natural gas consumption and economic growth: The role of foreign direct investment, capital formation and trade openness in Malaysia. Renewable and Sustainable Energy Reviews, 42, 835-845. 
Tamazian, A. and Bhaskara, R.B. (2010). Do economic, financial and institutional developments matter for environmental degradation? Evidence from transitional economies. Energy Economics, 32(1), 137-145.

Taylor, M. and Sarno, L. (1998). The behavior of real exchange rates during the postbretton woods period. Journal of International Economics, 46, 281-312.

Topal, M.H. ve Hayaloğlu, P. (2017). Farklı gelişmişlik düzeylerinde kurumsal kalitenin çevre performansı üzerindeki etkisi: Ampirik bir analiz. Sosyoekonomi, 25(32), 189-212.

Wang, N., Zhu, H., Guo, Y. and Peng, C. (2018). The heterogeneous effect of democracy, political globalization and urbanization on PM2.5 concentrations in G20 countries: Evidence from panel quantile regression. Journal of Cleaner Production, 194(1), 54-68.

You, W.H., Zhu, H.M., Yu, K. and Peng, C. (2015). Democracy, financial openness and global carbon dioxide emissions: Heterogeneity across existing emission levels. World Development, 66, 189-207.

Yerdelen, Tatoğlu F.(2020). İeri panel veri analizi. İstanbul: Beta Yayınları.

\section{Kaynakça Bilgisi / Citation Information}

Atay Polat, M. ve Çuhadar, P. (2021). Demokrasi ve yenilenebilir enerjinin çevre kirliliği üzerine etkisi: görünürde ilişkisiz regresyon analizi. OPUS-Uluslararası Toplum Araştırmaları Dergisi, 18(41), 3329-3361. DOI: $10.26466 /$ opus.888826. 